NBER WORKING PAPER SERIES

MONETARY AND EXCHANGE RATE

POLICY COORDINATION IN ASEAN+1

\author{
William H. Branson \\ Conor N. Healy \\ Working Paper 11713 \\ http://www.nber.org/papers/w11713
}

\author{
NATIONAL BUREAU OF ECONOMIC RESEARCH \\ 1050 Massachusetts Avenue \\ Cambridge, MA 02138 \\ October 2005
}

We thank the United Nations Development Program for support for this project, and Peter Kenen, Minh H. Pham, Elena Tchernykh, and seminar participants at the Hong Kong Institute for Monetary Research and the City University of Hong Kong for useful comments. The views expressed herein are those of the author(s) and do not necessarily reflect the views of the UNDP or the National Bureau of Economic Research.

(C2005 by William H. Branson and Conor N. Healy. All rights reserved. Short sections of text, not to exceed two paragraphs, may be quoted without explicit permission provided that full credit, including $\odot$ notice, is given to the source. 
Monetary and Exchange Rate Policy Coordination in ASEAN+1

William H. Branson and Conor N. Healy

NBER Working Paper No. 11713

October 2005

JEL No. F33, F41, G15

\section{$\underline{\text { ABSTRACT }}$}

This paper develops the basis for monetary and exchange rate coordination in Asia as part of a package of monetary integration that could support growth and poverty reduction. This could be achieved directly through coordinated exchange rate stabilization, and indirectly through the implications of this for reserve pooling and investment in an Asian development fund (ADF) and through development of the Asian bond market (ABM). Macro policy coordination could be viewed as a necessary condition for further development of both reserve pooling via the Chiang Mai Initiative (CMI) and of the ABM. The paper analyzes the trade structure of ASEAN and China in terms of both geographic sources of imports and markets for exports, and of the commodity structure of trade. The similarities of the geographic and commodity trade structures across the region are consistent with adoption of a common currency basket for stabilization, and with an argument for monetary integration across the region along the lines of Mundell (1961) on optimum currency areas. The paper constructs currency baskets and real effective exchange rates (REERs) for the countries in the region. Since their trade patterns are quite similar and their policies are already implicitly coordinated, their REERs tend to move together. This means that ASEAN and China are already moving toward integration in practical effect. Explicit movement toward coordination could support surveillance and reserve-sharing under the $\mathrm{CMI}$, and release reserves to be invested in an ADF.

William H. Branson

Department of Economics

Princeton University

Princeton, NJ 08544

and NBER

wbranson@princeton.edu
Conor N. Healy

Woodrow Wilson School

Princeton University

Princeton, NJ 08544

chealy@princeton.edu 


\title{
Monetary and Exchange Rate Policy Coordination in ASEAN+1.
}

\author{
William H. Branson and Conor N. Healy
}

\section{Introduction.}

This paper develops the basis for monetary and exchange rate coordination in Asia as part of a package of monetary integration that would be aimed at supporting growth and poverty reduction. This could be achieved directly through coordinated exchange rate stabilization, and indirectly through the implications of this for reserve pooling and investment in an Asian development fund (ADF) and through development of the Asian bond market (ABM). By monetary and exchange rate coordination here we mean flexible joint management of exchange rate movements against a common basket that is aimed at maintaining real effective exchange rates (REERs) near their equilibrium values as underlying real economic conditions evolve. The paper focuses on establishing the conditions for such coordination. Implications for reserve sharing, the ADF, and $\mathrm{ABM}$ development are the subject of continuing research.

Figure 1: The relationship of policy coordination, reserve sharing and the $A B M$

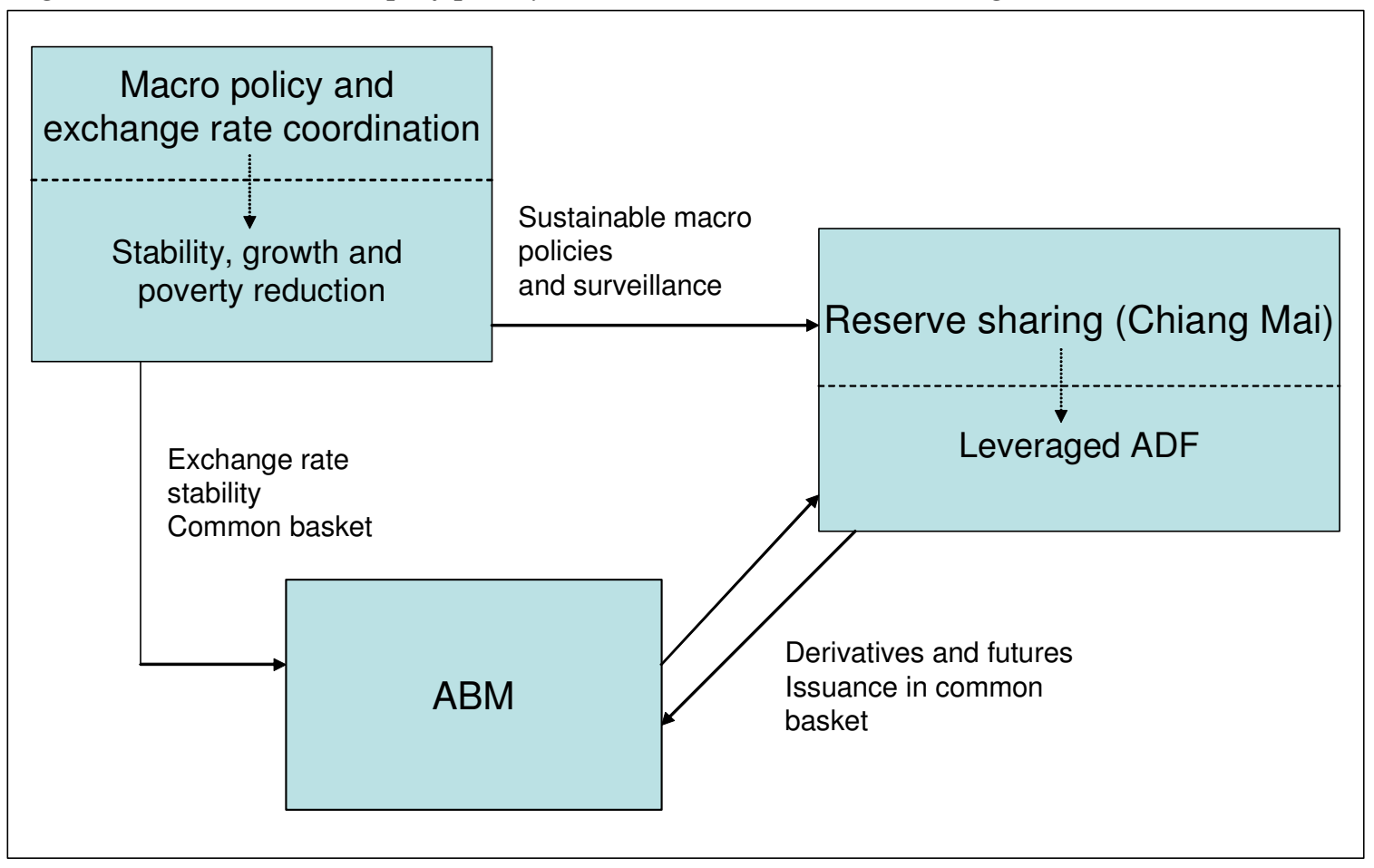


The relationship of exchange rate and macro policy coordination with reserve sharing and the ABM is summarized in Figure 1, above. Macro policy coordination can contribute directly to stabilization and growth by crisis prevention and reduction of uncertainty. It could provide the basis for surveillance, activating reserve sharing. The reduction in the demand for reserves at the individual country level could release resources for investment in development through the ADF. Exchange rate stabilization and the additional flow of investment resources could stimulate development of the ABM, increasing the efficiency of resources for investment in growth and poverty reduction. Thus macro policy coordination could be viewed as a necessary condition for further development of both reserve pooling via the Chiang Mai Initiative (CMI) and of the ABM.

Reserve pooling through the CMI structure and development of the ABM have received substantial attention to date. See, for example, Kuroda and Kawai (2003) and Nasution (2005). The political cooperation involved in the CMI and the rhetorical ambition of recent ASEAN and Chiang Mai government statements have been taken by many as suggesting a new era in region-wide monetary coordination. In practical terms though, actual progress has been more limited. The CMI swap agreements have not been activated, and the ABM is still mostly denominated in Singapore or US dollars.

Policy coordination could strengthen the basis for surveillance under the CMI, a necessary condition for effective reserve sharing. Exchange rate stabilization against a common basket of currencies could reduce risk in bond markets and facilitate development of derivatives and futures. Just as was the case with European monetary coordination (and the use of the European Currency Unit), the common basket could act as a focal point for monetary coordination. Moreover, it could also act as a spur for the $\mathrm{ABM}$, in particular through offering a broadly accepted local currency for bond issues. These are necessary conditions for development of an active ABM denominated in the currencies of the region. Since macro and exchange rate stabilization seem therefore essential for successful development of the CMI and the ABM, this is the focus of this 
paper. In further research, we expect to build on this analysis and look more closely at reserve sharing and the ABM.

Section II focuses on the potential gains from policy coordination, mainly within ASEAN. These can be separated into three sources. The first is direct gains from stabilization with sustainable macro policies. These might have prevented the crisis in 1997-9. The second is gains from cooperative stabilization to rule out unintended competitive devaluations and cascading speculation from market to market as was seen in the crisis. The third is indirect benefits gains in terms of the importance of stabilization for $\mathrm{CMI}$ and $\mathrm{ABM}$ development. The section focuses on the first two sources of gains, using an analytical narrative of the key macro developments in ASEAN since the early 1990s as its vehicle. Macro and exchange-rate policy coordination could have at least cushioned the effects of the 1997-99 crisis, and prevented at least partially the growth slowdown that followed.

Sections III-V support the analysis presented in section II. In section III the trade structure of ASEAN and China is laid out in terms of both geographic sources of imports and markets for exports, and of the commodity structure of trade. The structure of trade by commodity and sources and markets is also summarized for major commodity groups. The similarities of the geographic trade structures across the region are consistent with adoption of a common currency basket for stabilization. The similarities of commodity structure in trade across the region are consistent with an argument for monetary integration across the region along the lines of Mundell (1961) on optimum currency areas. The even distributions of trade across sources and markets for the major commodities show that stabilization against a common basket would not create strong differential sectoral strains across the region.

Section IV draws on the geographic data of Section III to construct currency baskets and real effective exchange rates (REERs) for the countries in the region. It complements the discussion of Section III, again providing support for the possibility of implementing a common (externally-based) currency basket. Since their trade patterns are quite similar and their policies are already implicitly coordinated (see Section V), their REERs tend to move together. This means that ASEAN and China are already moving toward integration in practical effect. Explicit movement toward coordination 
could support surveillance and reserve-sharing under the CMI, and release reserves to be invested in an ADF. If these were invested as paid-in capital, this could be leveraged in international financial markets.

Section V draws attention to the effective coordination of monetary policy by studying correlations among monthly movements in nominal exchange rates and changes in reserve money, representing monetary policy. The correlations are positive and quite strong. This is consistent with common reactions to common shocks or with attempts to maintain exchange rates within a stable zone within the region. In this case, monetary policy coordination is already implicit. Making the coordination explicit, or even formal, could yield the benefits of ruling out competitive devaluations and forestalling cascading speculation. This could contribute to the results for an ADF and development of the ABM described above. Section VI ends with some tentative conclusions and directions for further work.

\section{Macro Policy Coordination.}

This section discusses potential gains from coordinated stabilization of real exchange rates, relating them to the crisis of 1997-99 and the periods before and since. Exchange rates can be stabilized successfully only if the underlying macroeconomic policies are sustainable. One of the lessons from the crisis is the loss from exchange rate stabilization with unsustainable underlying policies and overheating. Thus "policy coordination" here assumes sustainable underlying macro policies. We discuss losses from non-stabilization terms of the events leading to the crisis in 1997-99, the loss of output in the crisis, and depressed investment and slower growth since the crisis. These are losses that could have been prevented or at least minimized by sustainable underlying macro policies and coordinated exchange-rate policies. We then go on to discuss potential gains from cooperative stabilization, and, more briefly, indirect gains in terms of reserve sharing, development of an Asian Development Fund (ADF), and the Asian Bond Market (ABM).

\section{Direct Gains from Stabilization: Summary.}


The direct gains from management of exchange rates so as to stabilize a real exchange rate come from the stability provided by the underlying macro policies and the resulting minimization of exchange risk to investors. A necessary condition for successful stabilization is a sustainable fiscal position that frees monetary policy to target inflation with exchange rate stability. A focus on exchange rate stabilization thus requires macro policy sustainability, a lesson learned (and being re-learned) in Europe.

The data for the ASEAN countries since the early 1990s provide an illustration of the problem of exchange rate stabilization without underlying macro sustainability, and the loss from failure of stabilization. The inverse of this loss is the gain from successful stabilization. These data are summarized shown in Graphs 2.1-2.3 (graphs and tables at the end). These summarize the obvious aspects of the crisis and its aftermath. After this summary we turn to data and analysis beneath these summary results.

Graphs 2.1 and 2.2 show monthly USD exchange rates for the core ASEAN countries, indexed to the beginning of 1990. These are defined as units of home currency per dollar, so up is depreciation of the home currency. The extreme movement of the Indonesian rupiah in 1997 distorts the picture in Graph 2.1, so Graph 2.2 eliminates Indonesia. Both graphs show the stable and roughly parallel movement of nominal dollar exchange rates before and after the crisis, interrupted by the crisis explosion in 1997-99. During the period before the crisis, USD exchange rates were stable in nominal terms. But the economies were experiencing investment booms not accompanied by fiscal adjustment, as shown in the tables in the next section. They were overheating, with inflation causing real appreciation of their currencies, although they were stable in nominal terms against the USD. They had large and growing current account deficits, and growing external debt denominated in foreign exchange. Thus the growth in the current account deficits was accompanied by appreciating real effective exchange rates, an unsustainable scenario that can be interpreted as a "bubble" in the FX market. These developments have been analyzed in a large and nuanced literature on the crisis. This includes Branson (2005), presented at the University of Malaya in Kuala Lumpur in 1998. We will summarize the central lessons of this episode for cooperative stabilization below. 
Exchange rate stability was restored in the period after the crisis. However, this period has seen a major depression in investment with current account surpluses. This is consistent with real appreciation, but slower real growth. The effects of the lack of sustainable policies and the breakdown of exchange-rate stability in the crisis are shown in Graph 2.3. There the paths of real GDP are interrupted by the crisis, with serious recessions in all the ASEAN countries. More importantly, none of the countries have recovered back to their original growth paths, and in all cases the underlying growth rate has been reduced. The unsustainable earlier policies and the crisis have depressed investment, lowered and slowed the real GDP growth path and substantially reduced the potential for poverty reduction. These losses from the failure of stabilization can be interpreted as the potential gains from successful stabilization.

\section{Investment, Saving, the Current Account, and REERs since 1990.}

The data on the current account, the investment-saving balance, and external debt for the core ASEAN countries since 1990 are summarized in Tables 2.1 and 2.2. The time series of the same data are shown in Graphs 2.4-2.7. The tables show in their first three lines the evolution of the current account balance (CAB), investment (I), and saving (S), all as percent of GDP. From the GDP accounts, these are connected by the equation $\mathrm{CAB}=\mathrm{I}-\mathrm{S}$. The current deficit is the excess of investment over saving. The current deficit must be financed by borrowing abroad, expanding the external debt. The last line of each table shows the path of the debt/GDP ratio for each country. The paths of the effective real exchange rates of the core ASEAN countries are shown in Graph 2.8. These are the total trade-weighted indexes from section IV below. We will analyze in turn the data for the pre-crisis period, 1990-96, the crisis, 1997-99, and the period since.

Pre-crisis, 1990-96. With the exception of Singapore, and Indonesia in the early 1990s, the tables show substantial and growing current deficits in the period before the crisis. These were generated by investment booms, with investment exceeding domestic saving. Investment and saving in the tables both include private and public. Thus the excess of investment over saving could have been remedied by an increase in public saving, that is, 
a fiscal tightening. In the absence of fiscal adjustment, the current deficits persisted and grew, maintaining or increasing the debt/GDP ratios in the last line of the tables.

The data for Thailand in Table 2.2 provide a good illustration of the stabilization problem before the crisis. From 1990 to 1996 investment was 41-42 percent of GDP, while saving was around 35 percent. Thus the current deficit stayed near 5 percent of GDP, increasing to over 6 percent in 1995-96, before the crisis. The ratio of external debt to GDP increased from 32 percent in 1990 to 62 percent in 1996 and 73 percent in 1997. The market could see that this path was unsustainable, and the speculative pressure against the Thai baht began the crisis in July 1997. The depreciation of the baht led to contagion across the region, and the cascade of devaluations shown in Graphs 2.1 and 2.2 above. Thus the crisis was the combined effect of unsustainable underlying macroeconomic policies and the lack of cooperative macro policy management.

The graphs show basically the same pattern for all the core ASEAN countries except Singapore. The investment ratios in Graph 2.4 are high and rising in the period up to 1997. The exception is Singapore, with investment fluctuating around 35 percent of GDP. The picture for saving is less clear in Graph 2.5. Thailand, Indonesia, and especially Philippines have saving ratios that are flat or falling. Malaysia's saving ratio increases during the period, and all the way until 1998. But through 1995, it is lower than the rising investment ratio in Graph 2.5. Singapore's saving ratio is rising until 1998, and exceeds investment.

The external consequences of the investment boom underfinanced by domestic saving are shown in Graphs 2.6 and 2.7. Graph 2.6 shows the decreasing current account balances for all the core ASEAN countries except Singapore. Thailand's and the Philippines' deficits are the most negative. Malaysia and Indonesia are closer to zero, with Malaysia's deficit diminishing after 1995. These patterns of current account balances are reflected in the debt/GDP ratios of Graph 2.7. With rapid GDP growth, the debt ratios of all but Thailand are stable until 1996-7. Thailand's debt ratio rises throughout the period 1990-1998, with an increase in its growth rate in 1994. This rapidly rising debt ratio is a signal of potential unsustainability, which led to the onset of the crisis in 1997. 
The depreciation of the Thai baht in July 1997, shown in Graphs 2.1 and 2.2 earlier, brought competitive pressure on the other ASEAN countries. This pressure was perceived by the markets, leading to cascading speculation and the devaluations in the other ASEANs. The source of the competitive pressure is in the similarity of their trade patterns, shown in section III below. The contagion of this pressure is one argument for cooperative exchange-rate management.

Movements of the REERs of the core ASEAN countries from 1990 are shown in Graph 2.8, moved forward from section IV on REERs. These are the REERs based on total trade weights for the six major markets outside ASEAN+1, indexed to $1989=100$. In the graph, an upward movement is a depreciation of the home currency. This follows from the definition of the exchange rate as units of home currency per unit of FX, e.g. rupiah per USD. The data of section IV show that ASEAN REERs weighted by export shares, import shares, and total trade move very closely together. This is due to the similarity in their trade patterns, shown in section III. For clarity, we focus here on the total trade-weighted REERs.

The REER paths in Graph 2.8 generally show a downward concavity from 1990 to 1996. There is an initial period of depreciation from 1990 to 1992, a more-or-less flat period from 1992 to 1994, and then an appreciation in 1995-1996. Again, the main exception is Singapore, with a real appreciation from 1989 to 1996, consistent with its rapid growth shown in Graph 2.1 earlier. Combined with the growing current account deficits in Graph 2.8, the REER paths are consistent with an unsustainability that developed into a bubble in the ASEAN FX markets, as shown analytically in Branson (2005).

The initial real depreciations in 1990-93 were broadly consistent with stable adjustment. They could contribute to correction of the current deficits. But the flattening out of the REER paths and the turn to real appreciation was a signal that the economies were moving away from equilibrium. The real appreciations would contribute to further growth in the current account deficits, rather than correcting them. As the markets saw this growing contradiction, speculation on depreciation developed, with the initial pressure on Thailand, the country with the rapidly growing debt ratio. The 
unsustainability of the underlying macro policies combined with the lack of coordination of exchange rate policy set the stage for the crisis that began with Thailand in July 1997.

Crisis, 1997-99. The crisis is clear in Tables 2.1-2.2 and Graphs 2.4-2.8. The collapse of the REERs of all the core ASEANs except Singapore is evident in Graph 2.8. The real depreciations in that graph range from 20 percent for the Philippines to 40 percent for Indonesia. With external debt denominated in FX and domestic assets in home currency, this collapse led to failures of financial institutions and a breakdown in credit. This phenomenon, in which currency crisis spreads to the financial sector is well known in the economic literature and is known as a "twin crisis". As the currencies collapsed, so did the local financial institutions, whose large dollar exposures were no longer matched by equivalent local currency assets. The financial collapse was precipitous. In Thailand, for example, 56 out of 91 finance companies were eventually liquidated. Similarly dramatic levels of collapse were seen elsewhere, especially in Korea and Indonesia (see for example, Radelet and Sachs, 1998). All of this combined with a major increase in uncertainty leading to the investment collapses shown in Graph 2.4. Investment fell by more than 50 percent in Indonesia, Malaysia, and Thailand and 25 percent in the Philippines. It fell even more steeply from 1997 to 2003 in Singapore. This investment collapse generated the recessions in GDP shown earlier in Graph 2.3.

The effects of the crisis on poverty are well documented (e.g. the World Bank's East Asia Update for September 2000). The crisis itself generated recessions and sharp increases in poverty across the region. Moreover, its costs in this regard have often been understated as, in the absence of the crisis, poverty rates would have declined further below pre-crisis levels. The effects of the crisis on poverty levels are summarized in Table 2.3. The table shows the substantial progress in reducing poverty across the region between 1990 and 1996, with the headcount percentage below \$1 and \$2 a day falling markedly. The crisis sees a strong reversal between 1996 and 1999, with the headcount living at under \$2 a day in 2002 still well above the 1996 level.

The results for external balance can be seen in Graph 2.6. With saving ratios fairly stable and investment collapsing, the current balances all moved sharply into surplus. This is essentially a macro result, since the currencies all depreciated in real 
terms during the crisis. Graph 2.7 shows the crisis results for external debt ratios. With debt mainly denominated in FX, the depreciations directly increased the debt ratios. The recessions in real GDP added to the increase, most markedly in Indonesia. Thus the investment collapse in the crisis led to the severe recessions, and the shift to current account surplus, while the depreciations increased the debt ratios. The combination of real recession, financial failures, and rising import prices contributed to significant increases in poverty, reversing the trend of a decade.

Post-crisis, 1999-2004. Since the crisis, the ASEAN economies have stabilized, with lower and slower paths of real growth (Graph 2.3), much lower investment ratios (Graph 2.4), current account surpluses, except the Philippines (Graph 2.6), and currencies depreciated in real terms (Graph 2.8). The lower investment paths are a serious source of concern, since capital formation was a driving force behind the "Asian miracle." See Alwyn Young (1995) for a fundamental discussion of investment and growth in Asia. The domestic saving ratios remain high, as shown in Graph 2.5. Thus excess saving in the region now generates current account surpluses and growth in reserves, as the Central Banks hold currencies stable.

The relationship between the paths of current account balances in Graph 2.6 and REERs in Graph 2.8, the main source of instability before the crisis, is mixed. The only country that stands out is Singapore, with a rising surplus and a depreciating currency, an unstable combination. Indonesia and Malaysia have substantial but decreasing surpluses with appreciating currencies in real terms, a stable combination. Thailand has a falling surplus with a slowly depreciating currency, and the Philippines has a small deficit with real depreciation.

In summary, the region has settled on a lower and slower, but stable growth path. Macro coordination centered on exchange rate management might have averted the crisis by leading to sustainable macro policies and reduced vulnerability to speculation. This is an underlying hypothesis for continued research.

\section{Gains from Cooperative Stabilization.}


Cooperative stabilization against a common currency basket can yield two potential additional benefits in addition to the direct benefits of stabilization just discussed. These are analyzed in some detail in Branson (2001). First, it rules out competitive depreciations. Charts 1 and 2 illustrate the problem. Once the pressure from speculation forced the devaluation in Thailand in July 1997, the other ASEAN countries had to follow. The market understood this, so the pressure moved to Indonesia and Malaysia. These depreciations were not competitive in the sense that they were aimed at achieving a competitive edge; they were forced by the market. But they had the same result. Once one goes, the others have to follow. This led to overshooting, as is evident in the graphs. A coordinated policy could have attained an orderly group devaluation, if needed, without the disorganization that at least partially contributed to financial failures and the depth of the recessions. The competitive nature of the depreciations is based on the similarities of the trade structures of the ASEAN economies both in terms of commodity composition and markets. This similarity is shown in section III. Explicit coordination of macro policy could work for sustainability and fit into rules of surveillance under the Chiang Mai agreement on reserve sharing. Implicit signs of coordination are discussed in section $\mathrm{V}$.

The second benefit is removal of convenient individual country targets from potential speculative pressure. In Asia in 1997, as in Europe in 1992, speculation could target the weakest country in the group, and then move sequentially from country to country. Coordinated stabilization with reserve sharing could remove this targeting convenience for speculation. If the coordination is based on an explicit agreement, the market will understand that it is facing a cooperative based on shared reserves. In this case, the group can come to a considered decision on dealing with speculative pressures.

Cooperative stabilization would be facilitated by development of a common currency basket for exchange rate management. The feasibility of agreement on this basket is supported by the similarity of trade composition among the core ASEAN countries and China in terms of markets and commodities, as shown in the next section. Thus a common basket in terms of currencies of export destination or import source could be developed as the basis for exchange rate coordination. These baskets are discussed in section IV. This could also be the basis for a basket for Asian bond issue. 


\section{Trade Structure: ASEAN and China.}

This section presents and analyzes the structure of ASEAN and China trade with two objectives. The first is to develop the basis for weights for baskets of ASEAN currencies in terms of major trade partners outside ASEAN and China. For individual countries these would be weights for calculating effective exchange rates, nominal and real. Movements of the real effective exchange rates (REERs) can be used as an indicator of existing implicit coordination among the ASEAN+1 countries. For ASEAN as a group, the weights would define a common basket for coordinated management of exchange rate policy. This common basket could also be used as the currency of issue in the Asian Bond Market.

Since the major currencies that are candidates for any basket are identified with the countries of issue or the regions using the currency, a discussion of weights for a basket must begin with the geographic distribution of trade. The weights would be based on the geographic distribution of trade across sources and destinations. So we first present the structure of trade by markets and sources to develop weights for REERs.

The second objective is to evaluate the case for some form of monetary integration of ASEAN+1 based on the commodity composition of trade. Here we reflect the original view of the basis for optimum currency areas of Mundell (1961). Countries with similar structures of trade by commodity are good candidates for integration into a currency area. Thus the next subsection presents the structure of trade of the region by commodity classes.

The last step is to present a summary of the structure of trade by market and commodity. This summarizes the similarities and differences of trade structure across the region. It can also yield an idea of the effects of stabilizing exchange rates against a geographic basket on fluctuations of profitability across commodity-producing sectors. The last subsection therefore turns to the structure by commodity and market.

\section{Geographic Structure of Trade.}

The geographic structure of trade for the core ASEAN economies and China is summarized in Tables 3.1 for exports and 3.2 for imports for 2003, the latest year 
available. Trade structure does not change very fast over time, so the particular choice of year is not crucial. The tables will be updated as more recent data become available. Each table shows the total trade of the ASEAN+1 countries [core ASEAN plus China] in \$bn, and its percentage distribution across markets for exports and sources for imports. We focus on the large ASEANs because inclusion of the small, newer members does not change the numbers at all significantly. The full structure of ASEAN trade is presented in appendix tables. In revision, we expect to integrate Hong Kong's trade with China.

Table 3.1 shows the structure of exports by markets for ASEAN+1. The first column gives total exports, and the rest give the percentage distribution across major markets. Taiwan and Australia are included among the major markets due to their regional importance; their shares of ASEAN+1 exports are similar to Korea's. In moving to weights for REERs, we will concentrate on the six markets that are external to ASEAN+1, treating trade in the region as internal. Here we begin with the broader picture. We note for future reference and research that the total value of Singapore's trade is exaggerated by its entrepot nature. It is not clear what, if any, effect this has on its trade distribution.

A first thing to notice in Table 3.1 is that the distribution of China's exports across markets is very similar to ASEAN's. The shares of the main six markets in the last row of the table fit right into the ASEAN pattern. This also holds for import sources in Table 3.2. This similarity of the geographic distribution of trade of ASEAN and China is a first indicator that the two may be good candidates for monetary coordination. We also note that total ASEAN exports at $\$ 427$ bn are about the same as China's.

Turning to some of the notable details of the table, we note that the share of ASEAN internal exports ranges from 17 to 28 percent. The share of China's exports to ASEAN is smaller, as are ASEAN's to China, around 6-7 percent. Thus as of 2003, ASEAN was a denser trade area than ASEAN-China. The total share of the three largest markets \{Japan, US, Europe $\}$ for all seven countries is in the range of 42 percent for Malaysia to 52 percent for Philippines. Again, China fits into the ASEAN distribution here. If we look at China separately, we see that the share of ASEAN exports to China falls between the large three markets $\{$ Japan, US, Europe $\}$, and the smaller three $\{$ Korea, Taiwan, Australia\}. 
The export market data of Table 3.1 would support the adoption of a common currency basket by both ASEAN and China including either the three largest markets \{Japan, US, Europe\}, or all six including \{Korea, Taiwan, Australia\}. Later we focus on REERs defined using the six-currency basket.

Table 3.2 shows the structure of imports by source for ASEAN+1. The table is set up the same as Table 3.1. As in Table 3.1, the distribution of China's imports across source is quite similar to ASEAN's. China's shares of imports from Korea and Taiwan are larger than ASEAN's, and the shares of the US and Australia are smaller. But the overall impression is that China's import pattern from the major markets fits into the ASEAN pattern, potentially supporting an argument for coordination. ASEAN's total imports of $\$ 356$ bn are about the same as China's $\$ 413 \mathrm{bn}$. Thus in terms of trade volumes, aggregate ASEAN and China are about the same size.

The share of ASEAN internal imports in Table 3.2 ranges from 17 to 29 percent, the same as the case for exports. The share of China's imports from ASEAN is smaller share, as are the shares of ASEAN imports from China. Thus on the import side intraASEAN trade is also denser then that between ASEAN and China. The total share of the three largest sources in imports is in the range of 39 percent for China to 48 percent for Philippines. The ASEANs are all in the range 40-50 percent. These total shares for the major sources are smaller than for exports, especially for China, with 51 percent for exports and 39 percent for imports. The US shares of imports in Table 3.2 are all smaller than the export shares in Table 3.1. Thus the imbalance between the export share and the import share for the three largest trading partners may be due to the US trade imbalance. As in the case of exports, the share of China in ASEAN imports falls between the three largest sources \{Japan, US, Europe $\}$ and the three smaller ones \{Korea, Taiwan, Australia\}.

The import source data of Table 3.2 would also support the adoption of a common currency basket by both ASEAN and China. Later we see that the movements of importweighted and export-weighted REERs are quite similar across the ASEAN countries and China.

Commodity or Sector Structure of Trade. 
The commodity structure of trade at the one-digit SIC level of the ASEAN countries and China (in 2002) is summarized in Tables 3.3 for exports and 3.4 for imports. The tables separate the founding "core" ASEANs from the later entrants plus Brunei. The latter are much smaller individually and in aggregate and have very different trade structures. China and China including Hong Kong are also presented separately, mainly due to the entrepot nature of Hong Kong's trade. [This problem is more striking and difficult in the case of Singapore] Inclusion of Hong Kong with China does not affect the data or conclusions significantly at this level of aggregation. The analytically important one-digit SIC sectors are disaggregated in Appendix Tables A3.3 and A3.6.

Table 3.3 for exports shows clearly the results of the "Asian miracle." SIC 7 is the dominant export sector for all of core ASEAN but Indonesia. [The 42.3 percent in SIC 9 for Philippines is probably unclassified SIC 6-8. Further work is coming on this. See also Myanmar.] The largest share of Indonesia's exports (in 2002) is in SIC 3, which includes oil. But if SIC 2 and 3 for Indonesia are excluded, the 16.8 percent in SIC 7 becomes 25 percent, still much less than the other core ASEANs. China's share of SIC 7 is about the same as Philippines and Thailand. If SIC 7 and 8 are aggregated, the commodity structure of China's exports fits into the ASEAN pattern, as with the market distribution earlier. China and the recent ASEAN entrants also have large shares in SIC 8 , which includes apparel as is seen below. This is a major difference from the core ASEANs.

Table 3.4 for imports shows a pattern that is dominated by manufactures (SIC 68), as is normal for industrializing countries. The core ASEANs (except Indonesia) and China, show particularly high shares in SIC 7. This is also the case for Laos and Brunei. Indonesia's import structure more closely resembles Vietnam. However, no particular pattern stands out in Table 3.4. Again, the structure of China's trade resembles that of the ASEANs.

Disaggregated SIC categories 6-8 at the 2-digit level are shown for exports and imports in Appendix Tables A3.3 and A3.4. [Appendix Tables are available directly from the authors.] There several patterns stand out. These are extracted into Table 3.5. On the export side in Table 3.5, the importance of SIC 75-77 for the core ASEANs and China is clear. Here again, China's trade fits in with ASEAN. The importance of SIC 
84-85 for the other ASEANs and to a smaller degree China is also clear. These are the apparel exporters of the region.

On the import side in Table 3.5, SIC 77 stands out for the core ASEANs and to a lesser extent China, reflecting intra-industry trade in electrical machinery. SIC 65 stands out for the other ASEANs. Their apparel industry imports textiles, to some extent from China -- see China's 5 percent in imports in SIC 65 in Table 3.5) -- and exports the finished product. This is also a pattern in S. Asia, especially Sri Lanka. These disaggregated data reinforce the similarity of China's trade to ASEAN's, an important condition for monetary coordination.

\section{Trade by Sector and Market.}

In this subsection we summarize the data on trade of core ASEAN and China by sector and market for exports and source by imports in SIC 6-8. The full set of data is in Appendix Tables A3.5 and A3.6. This will give us information on potential differential effects on sectors of coordinating exchange rate policies on a common basket. The same movement of the exchange rate would have differing effects on the aggregate economy of each country depending on the sectors with the largest differences in trade shares across markets and sources. Similar distributions of trade by sectors and markets or sources will minimize differential impacts within the economies; dissimilar distributions will increase these differences, making coordination more costly. We see here that the distributions of shares across markets for the major commodities are fairly even, minimizing this source of disruption from coordination on a common basket.

Tables 3.6-3.8 show the distributions of manufactured exports by markets for the core ASEAN countries and China in SIC 6-8. The entries in each line show first the fraction of total exports in the SIC category, and then the share of total exports in that category separately to each market. The total shares for SIC 7 in Table 3.7 are the largest for the core ASEANs except Indonesia, and for China. More than half of total exports are SIC 7 for Malaysia and Singapore. With some exceptions, exports in Tables 6-8 are evenly distributed across markets. Notable exceptions might be the small share of the US in Malaysia's exports in SIC 6 and the large share in SIC 7; and the small share of the US 
in Philippines exports of SIC 7. These sectors could be differentially affected by movements of the US dollar within a common basket.

Tables 3.9-3.11 show the same distributions for imports by source. These distributions seem even more even than for exports. One exception might be the low US shares of SIC 6 exports to Malaysia and Philippines in Table 3.9. To summarize, the data of Tables 3.6-3.12 do not show serious imbalances across major sources and markets in the distributions of trade by sectors. Thus coordinated exchange-rate stabilization against a common basket based on these sources and markets should not create substantial differential sectoral pressures within ASEAN or China.

\section{Currency Baskets and Real Effective Exchange Rates.}

This section discusses the construction of currency baskets and REER indexes for the core ASEAN countries and China. These are based on trade of ASEAN+1 outside this region, since the focus of the study at this stage is on first intra-ASEAN coordination, and then coordination of ASEAN with China. Similar baskets and REERs can be calculated for the ASEAN member's largest trading partners, regardless of region, or for ASEAN +2 or 3 against major trading partners outside the region. The requisite data are readily available. We begin by presenting the alternative weights for exports, imports, and total trade, based on the data from section III. Next the alternative REER measures are shown and discussed. We see that their movements are quite similar across indexes (exports, imports, total trade) and countries, confirming the case for coordination.

The REERs combine movement of nominal exchange rates and domestic price levels, both at least partially under the control of the domestic monetary authority, and trading partner's price levels, which are independent of domestic policy. Therefore, the similarity of movement of REERs across countries implies some form of policy management of movements of domestic inflation and the nominal exchange rate that maintains this similarity in REER movements. This is presumably aimed at maintaining competitiveness in the region without competitive devaluations. To analyze this policy management we show the decomposition of movements of the import-weighted REERs at the end of the section. 


\section{Weights for Currency Baskets.}

The weights for currency baskets based on exports, imports, and total trade of ASEAN plus China are shown in Tables 4.1-4.3. Tables 4.1 and 4.2 are taken directly from Tables 3.1 and 3.2, scaled to 100. Table 4.3 is based on the total shares from Tables 3.1 and 3.2. The trade shares are quite similar across countries in each table, and across tables. Exceptions might be Indonesia, with a high weight for Japan and a low weight for the US on the export side, and Thailand, with a high weight for Japan on the import side. The weights for China are well within the ASEAN distribution in all three tables.

The similarities of the weights among the ASEAN countries suggest that a common currency basket could fit ASEAN. This would serve for coordination of exchange-rate policy and as the basis for security issuance in the ABM. Clearly common weights would have to be the subject of eventual discussion and negotiation within ASEAN. The similarity of ASEAN weights to China suggests that eventual coordination of ASEAN exchange-rate policy on a similar basket as China could be feasible. A common basket would fit both fairly well.

\section{REER Indexes.}

Graphs 4.1, 4.2, and 4.3 show the movements of the REER indexes using the alternative weights from Table 4.1-4.3. The export-weighted and total trade indexes use GDP price indexes, which include exports but not imports. The import-weighted indexes use CPIs, which include imports but not exports. The ASEAN indexes for total trade from Graph 4.3 are the ones used in Graph 2.8 earlier. All three graphs show the stable pattern of REERs before and after the crisis of 1997-98. The REERs of the core ASEANs except Singapore show sharp depreciations in the crisis period. Singapore has a milder depreciation of about 15-20 percent from 1996 to 1999 on export and total trade basis, but only 5 percent on import basis. China's REER moved differently, with an early appreciation in 1995-97, and then a small depreciation. Thus Singapore and China escaped the contagion of the crisis.

The graphs show the highly similar movements of the country indexes across sets of weights. This is expected from Tables 4.1-4.3, where country weights are similar across baskets. They also show similar movements across the ASEAN countries, with 
China moving somewhat independently. Before and after the crisis, though, the REER indexes, including China, show no trend or tendency to diverge. They tend to stay within a fairly well-defined range. After 2000, they seem to tend to converge. This suggests that policies are at work in the background that tend to stabilize REERs in the region, and even make them tend to converge. Such policies would be consistent with an implicit coordination of nominal exchange rate movements aimed at REER stability that maintains competitive positions. This policy stance can be seen when the REER movements are decomposed into their nominal components.

The broad synchronicity of the REER movements across the ASEAN+1 countries tells us that it would be possible to construct a common basket with relative ease. The relative export and total trade weightings behind these graphs (and shown in Tables 4.1 and 4.3) support this case. The trade structure of these countries is broadly similar, with each country having roughly the same proportions of trade with major trading partners such as Japan, the U.S. and Europe. It would therefore be possible to construct a basket currency based on external or total trade and the regional governments could use this currency as a focal point against which to coordinate exchange rate policy. In a similar way the countries of the European Monetary System (EMS) used the basket European Currency Unit (ECU) to coordinate their exchange rate policies (though with the distinction that the ECU was an internally based basket currency). Such a basket currency could be used to manage regional stabilization and to address such specific regional concerns as export competitiveness and the response to externally driven shocks. It would also be a natural unit of denomination for ABM issues.

\section{Nominal Components of REERs.}

The REER is the nominal exchange rate adjusted for relative price levels. Specifically here it is constructed as the product of a nominal exchange rate index times the ratio of a trading partner's price index to the domestic price index. In symbols, the REER index e is defined as $\mathrm{e}=\mathrm{EP}^{*} / \mathrm{P}$, where $\mathrm{E}$ is the nominal effective exchange rate (NEER) index and $\mathrm{P}^{*}$ is the trading partners' price index, all defined by the same set of weights, and $\mathrm{P}$ is the domestic price index. The trading partner's price index $\mathrm{P}^{*}$ is not substantially affected by domestic policies, but the NEER and P are. Thus policy to 
stabilize a REER must work on the co-movement of E and P to be consistent with that of $\mathrm{P}^{*}$. For example, with a stable $\mathrm{P}^{*}$, domestic inflation in $\mathrm{P}$ must be matched by depreciation of E. This is illustrated in Graphs 4.4-4.6. These show the components of the REERs weighted by import shares. These are chosen because they use CPIs as the price indexes. These tend to be the focus of inflation perceptions and policies more than GDP deflators.

Graph 4.4 shows the movement of the weighted CPIs for trading partners. These are the $\mathrm{P}^{*}$ indexes. They move closely together since they differ only in their weights across countries, which we have seen are quite similar. The graph shows a general inflationary trend of about 2 percent per year for trading partners. Graph 4.5 shows highly divergent movements of domestic price indexes, the Ps. These range from nearly flat for Singapore to an average of about 11.5 percent a year for Indonesia, with a jump in the crisis. Graph 4.6 shows the movement of the nominal exchange rate indexes E. These are similar to the movements of the price indexes in the previous graph. Thus policy pressures on domestic price levels and nominal exchange rates tend to produce parallel movements that produce the stability of REERs shown earlier.

Coordination of macro policies in ASEAN would work on both nominal variables $\mathrm{P}$ and E. Coordination of sustainable macro policies domestically can work to stabilize price levels $\mathrm{P}$ across countries around an acceptable rate of inflation. This is the objective of surveillance. Coordination of exchange-rate policies can work to stabilize E. The combination would maintain stable and competitive REERs with an acceptable inflation trend in the region. In the absence of sustainable domestic macro policies that stabilize $\mathrm{P}$ around the acceptable trend, price levels will diverge as in Graph 4.5, and require trends in nominal exchange rates to maintain stability in REERs. A combination of surveillance of sustainable domestic macro policies and coordinated exchange rate policies would be a macropolicy coordination package promoting growth and poverty reduction.

\section{Implicit Exchange Rate and Monetary Policy Coordination.}

There is already a surprising degree of implicit coordination of exchange rate policies among the ASEAN countries, or even the ASEAN+3. Tables 5.1 and 5.2 show 
the correlations of monthly changes of USD exchange rates for the ASEAN+3 countries for the post-crisis period. Table 5.2 shows the full group and Table 5.1 eliminates the smaller ASEANs. In Table 1 all the correlations are positive. The correlations for China and Malaysia are small, since these countries essentially fixed their currencies against the USD during this period. The others show generally strong positive correlations, indicating common co-movements against the dollar.

Similar results are shown in Tables 5.3 and 5.4 for monthly changes in reserve money. These are all quite positive for core ASEAN and ASEAN+1, indicating monetary policy movement consistent with effective exchange rate coordination. These results show that movement to explicit coordination does not require a large change in actual policy positions. The ASEANs, and ASEAN plus China, already conduct monetary policy in such a way as to maintain stability in exchange rates and REERs, as seen in section IV. The policies are implicitly coordinated, as seen in the correlations here. A movement to explicit coordination would present a common posture to the markets and diffuse speculative pressure when it arises. It would also support reservesharing as under the CMI. This could permit the release of reserves to be invested as paid-in capital into an $\mathrm{ADF}$ that could leverage it in international markets to become a real influence for development in the region.

\section{Conclusions and Further Research}

This paper has examined the prospects for macro policy and exchange rate coordination in Asia (in particular in the ASEAN and in the ASEAN and China area) and looked at the potential implications of such coordination for reserve sharing and financial developments such as the ADF and the ABM. The paper makes an assessment of the gains from such coordination. The direct gains from exchange rate management come from the stability provided by the underlying macro policies and the resulting minimization of risk to investors. The paper looks at the loss from non-stabilization in terms of the economic over-heating leading to the crisis of 1997-9; the loss of output and poverty growth from the crisis; and the depressed investment and slower growth since the crisis. We argue that better coordination of the underlying macro policies could have prevented or minimized such costs, in particular with beneficial consequences for pre- 
crisis policy, the control of exposure to speculative contagion and for post-crisis investment recovery.

We argue that the existing geographic and commodity structure of the region's trade mean that REER's already move together, ensuring a minimum autonomy loss from policy coordination. We look at the geographic structure of trade, using this to develop weights for baskets of ASEAN currencies in terms of major trade partners outside ASEAN and China. Such weights are broadly similar for the main ASEAN countries. The movements of real effective exchange rates are also broadly synchronous. This highlights an existing implicit coordination amongst the ASEAN +1 countries and suggests that use of a common basket for exchange rate coordination would not mark a radical departure for existing policies or from domestic autonomy. We additionally look at the commodity composition of trade for the ASEAN+1 countries. Once again, this composition is broadly similar for the larger ASEAN+1 countries (SIC 7 being the dominant export sector and the manufactures of SIC6-8 dominating imports). Such a similar commodity structure implies greater benefits from coordination, as argued by Mundell's Optimal Currency Area theory. Overall, the trade data by both sector and geography show no serious imbalances across major sources and markets. A coordinated exchange rate stabilization against a common basket based on these sources and markets shouldn't create substantial differential pressures within ASEAN or China.

We construct real and nominal effective exchange rate measures for the countries of the region. These rates show the moves toward integration already in practical effect in the region and underline the ease of any potential transition toward greater coordination. In particular, they highlight how an externally-based currency basket might easily be constructed, offering a focal point for greater regional integration. Similar to the European Currency Unit in the European Monetary System, such a basket currency could permit greater coordination of regional policies, addressing particular regional concerns regarding competitiveness and the response to externally-driven shocks or cascading speculation. It would yield direct benefits for growth and poverty reduction, as well as setting the foundation for further cooperation in the areas of reserve sharing and developing the ABM. The regional currency unit would provide a natural basis for the denomination of $\mathrm{ABM}$ issues. 
We see this paper as the first part of a broader study of exchange rate and monetary coordination in the region. In further research we propose to build on this analysis and look more closely at reserve sharing and the ABM. As we have outlined in Figure 1, we see all of these as closely tied together. We also intend to look more closely at the political economy of regional cooperation in these areas. 


\section{References}

Branson, William H., 2001, "Intermediate Exchange-rate Regimes for Groups of Developing Countries," in J.B.de Macedo, D. Cohen, and H. Reisen (eds), Don't Fix, Don't Float OECD, Paris, 2001.

Branson, William H., 2005, "The Asian Crisis as a Bubble in Foreign Exchange Markets," mimeo.

Kuroda Haruhilo, Kawai, Masahiro, 2003, "Strengthening Regional Financial Cooperation in East Asia," PRI Discussion Papers 03A-10 (May 2003), Policy Research Institute, Ministry of Finance, Tokyo.

Mundell, Robert, 1961, "A Theory of Optimal Currency Areas," American Economic Review (September 1961) vol.51 pp.657-65.

Nasution Anwar, 2005, "Regional Financial Arrangements in East Asia," AEA-ACAES Joint Meetings (January 2005), forthcoming in Journal of Asian Economics.

Radelet Steven, Sachs Jeffrey, 1988, "The Onset of the East Asian Financial Crisis," NBER Working Papers 6680 (August 1988), National Bureau of Economic Research, Inc.

World Bank, 2000, "East Asia Update, Special Focus: Poverty During Crisis \& Recovery", World Bank, East Asia and Pacific publications, (September 18, 2000) pp.16.

Young Alwyn, 1995, "The Tyranny of Numbers: Confronting the Statistical Realities of the East Asian Growth Experience." Quarterly Journal of Economics 110 (August 1995): 641-680. 
Graph 2.1: Monthly exchange rates for core ASEAN, December 311989 until present

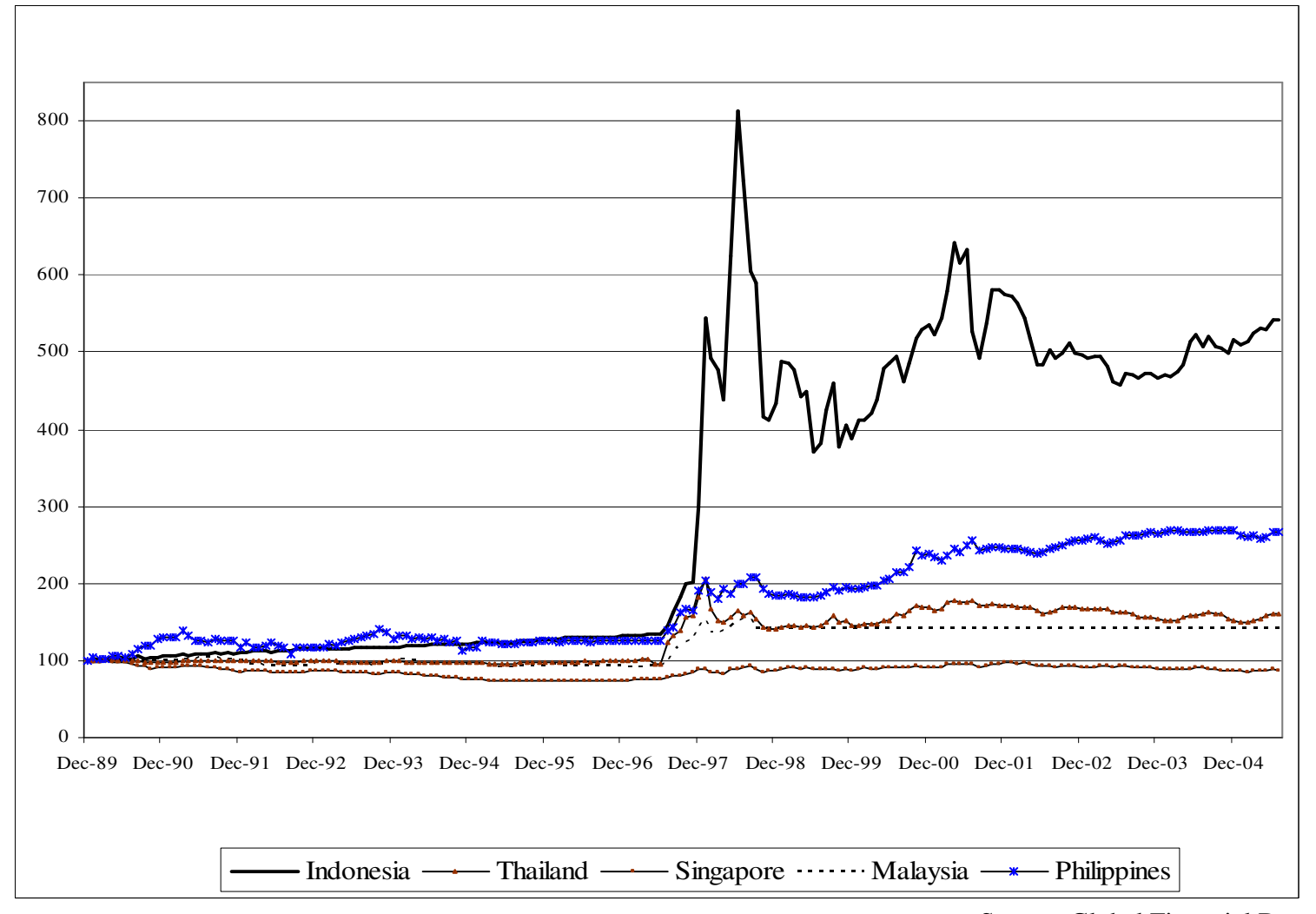

Source: Global Financial Data

Graph 2.2: Monthly exchange rates for core ASEAN, excluding Indonesia, December 31 1989 until present

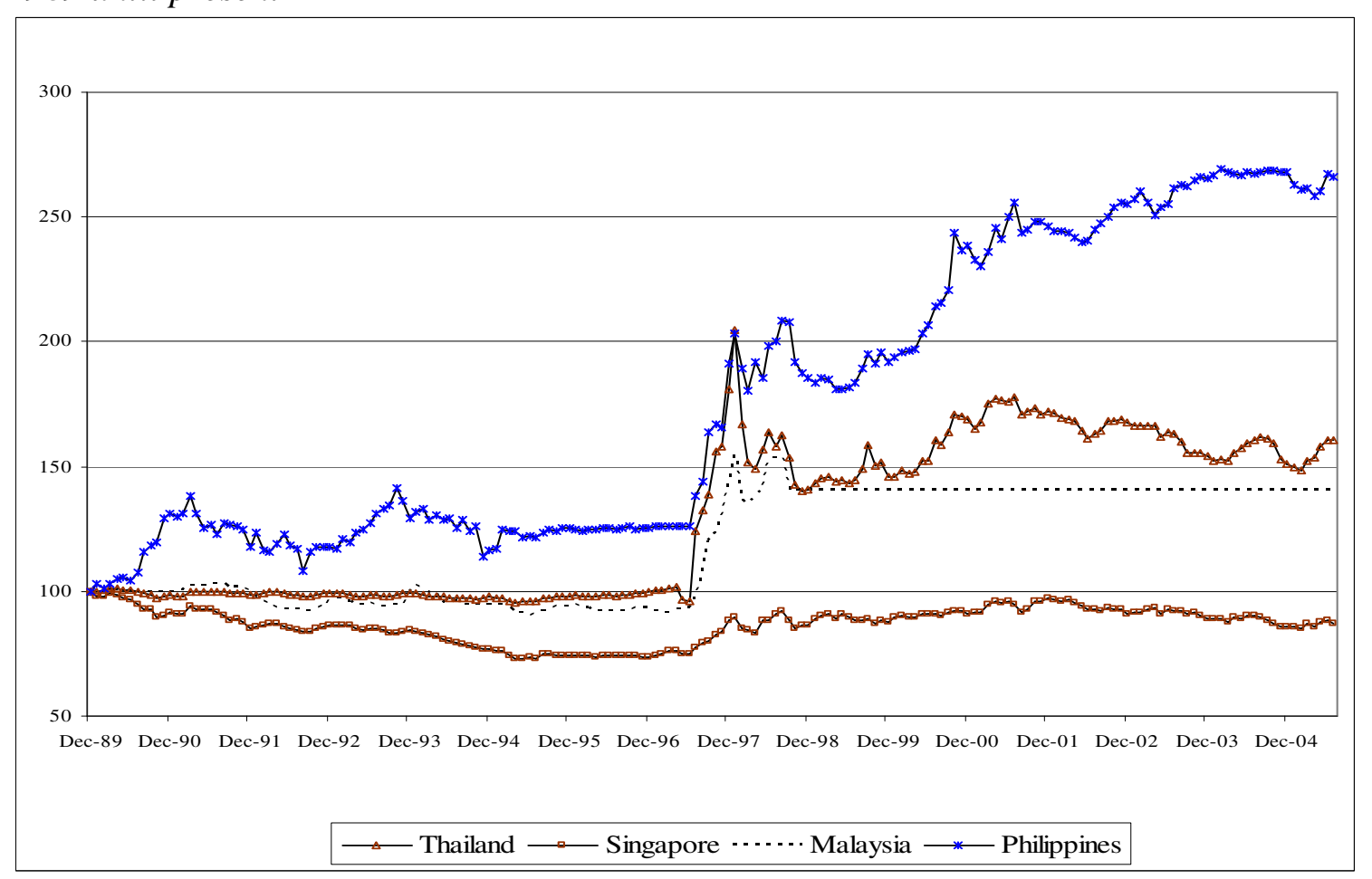

Source: Global Financial Data 
Graph 2.3: GDP (constant, 2000 LCU)

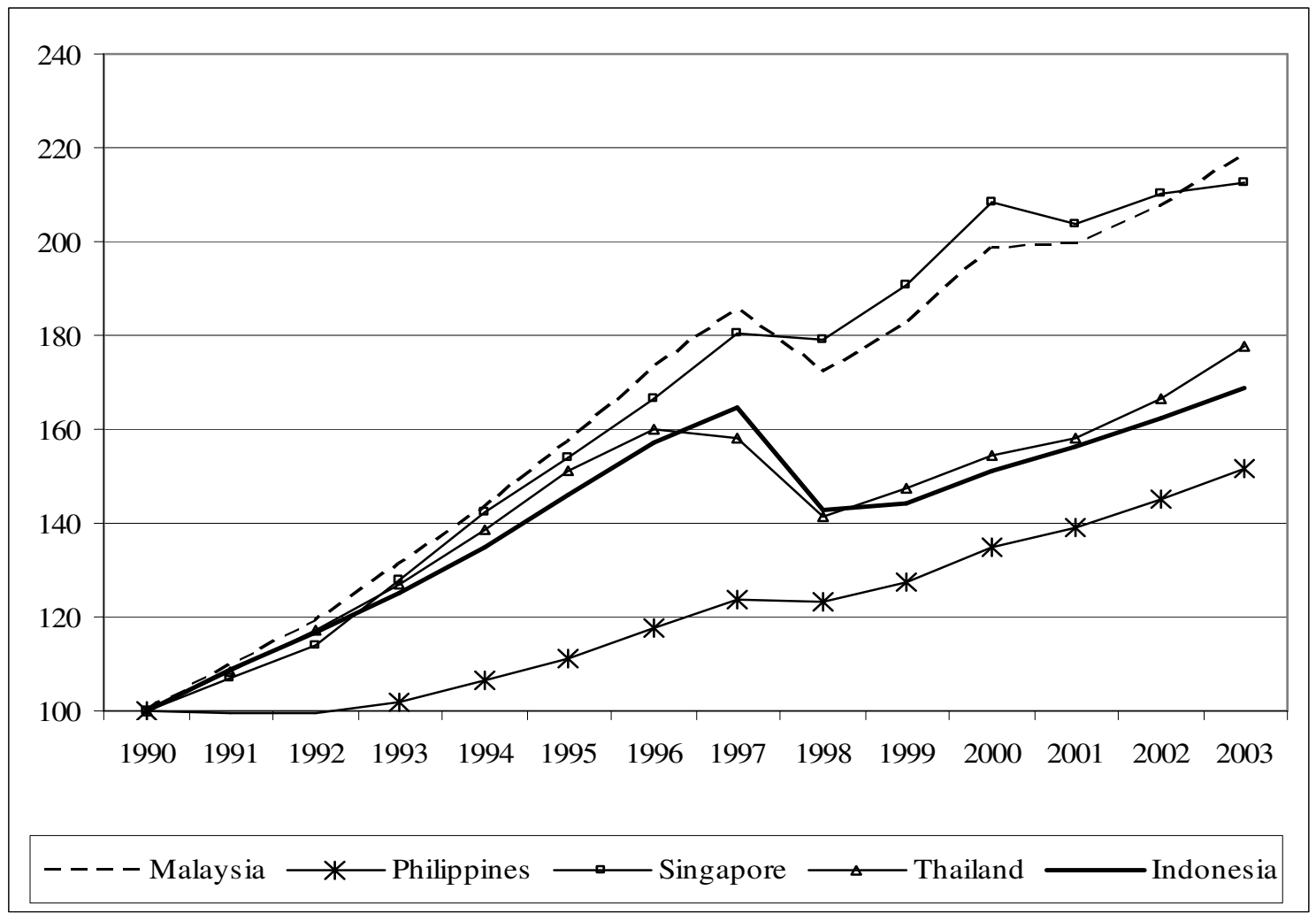

Source: World Bank, WDI database

\section{Graph 2.4: Gross capital formation (\%GDP)}

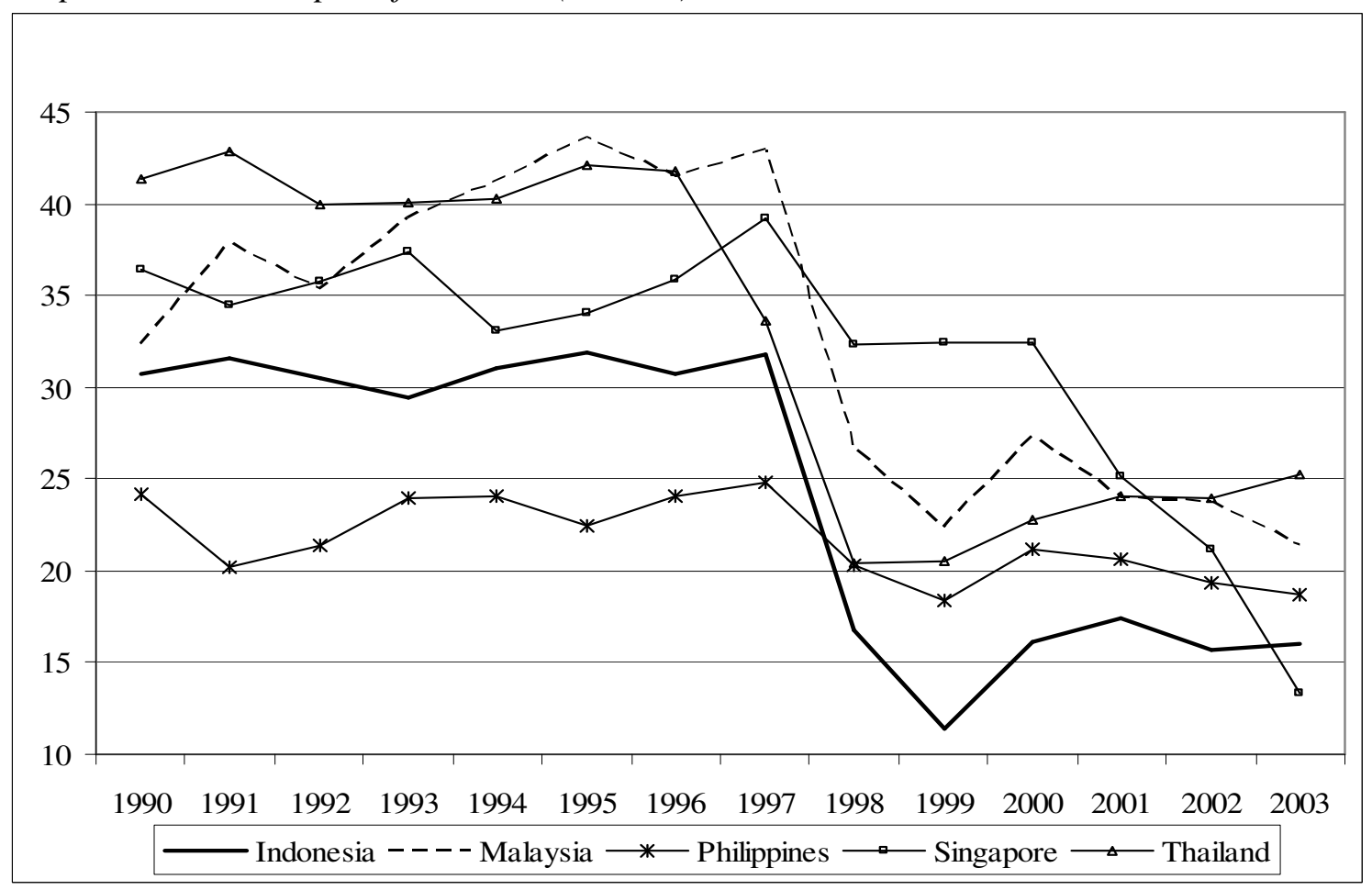


Graph 2.5: Gross domestic savings (\% GDP)

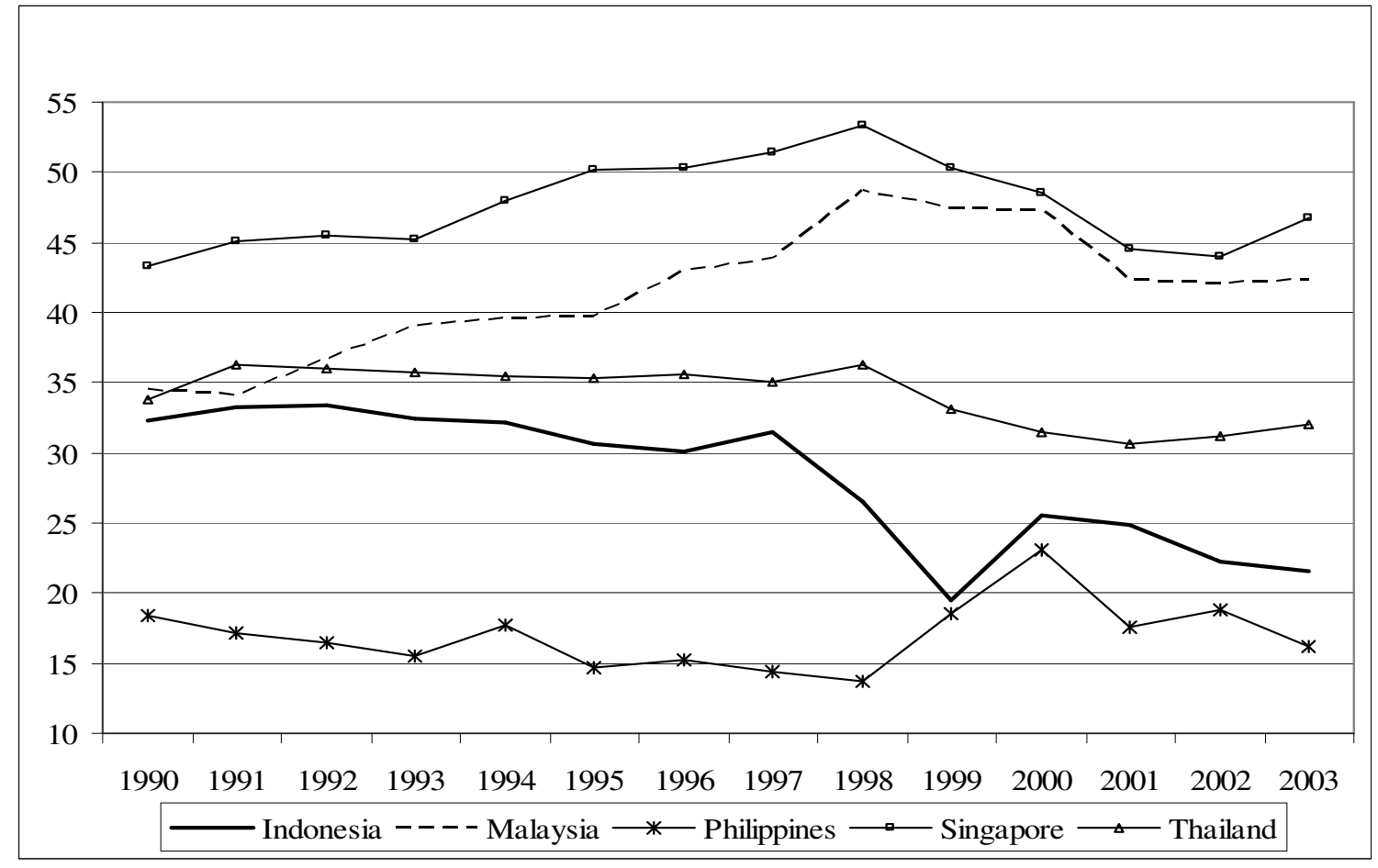

Source: World Bank, Word Development Indicators

Graph 2.6: External balance on goods and services (\% GDP)

Source: World Bank, Word Development Indicators

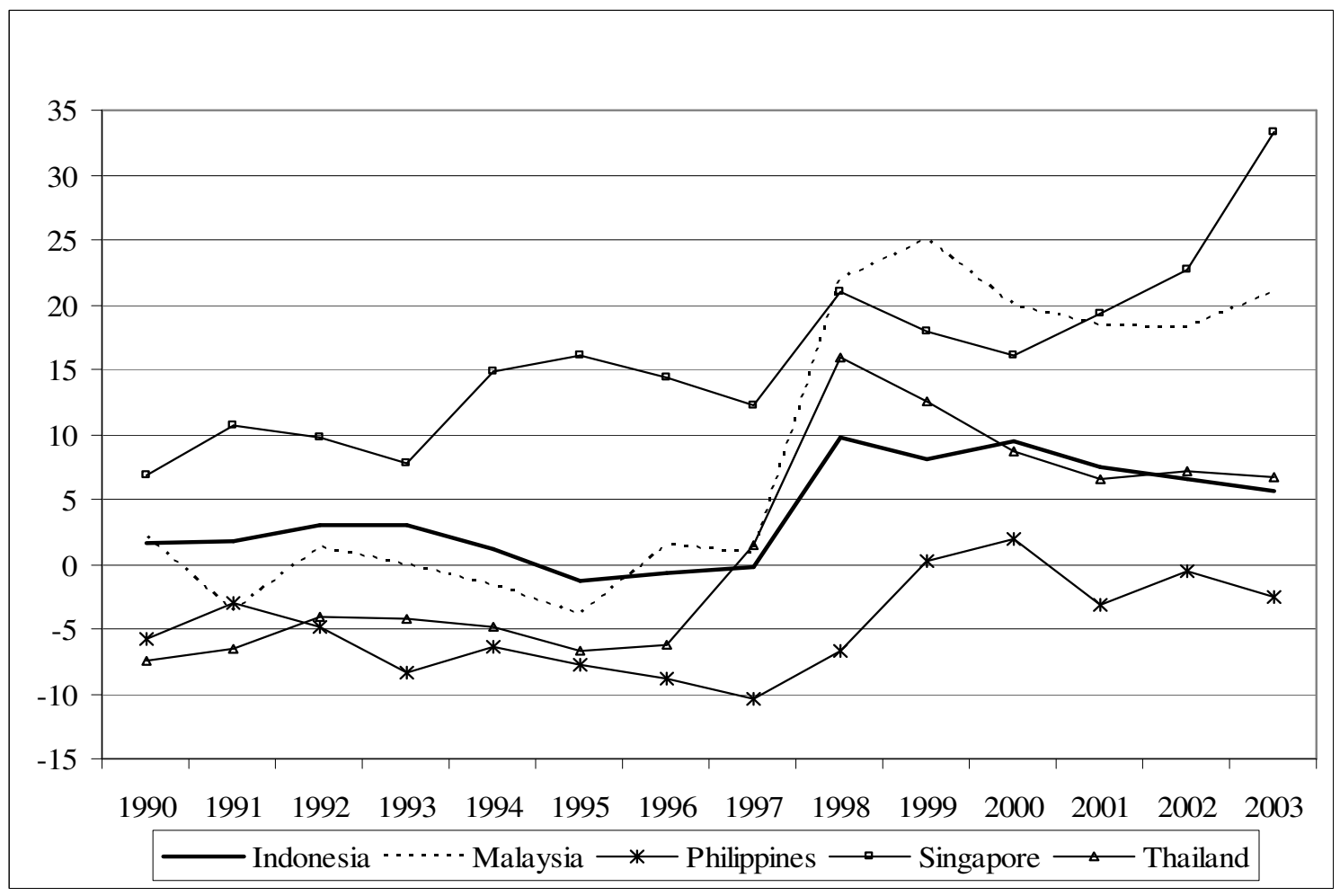


Graph 2.7: External debt (\% GDP)

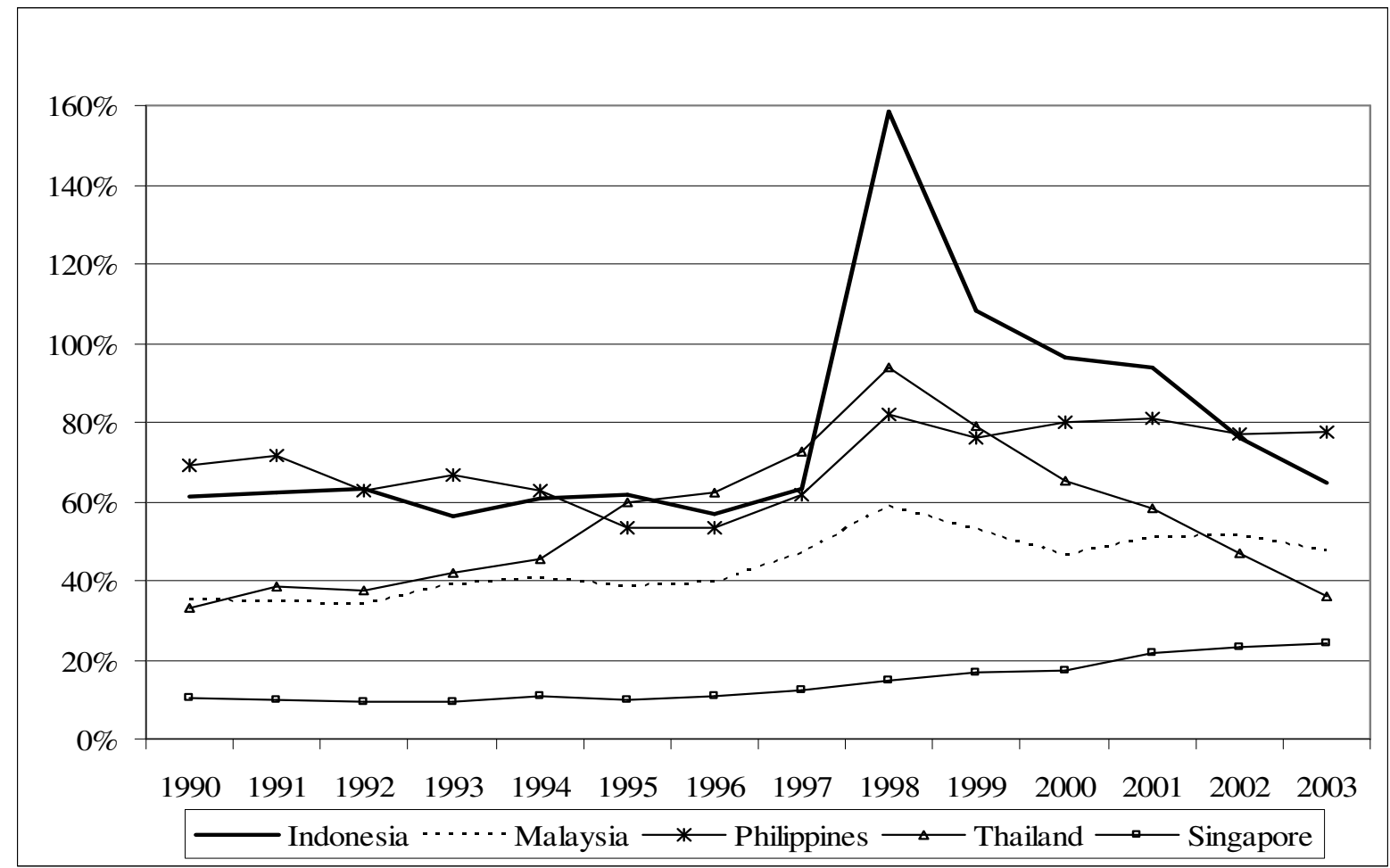

Graph 2.8: Real effective exchange rate

Source: Economist, EIU data

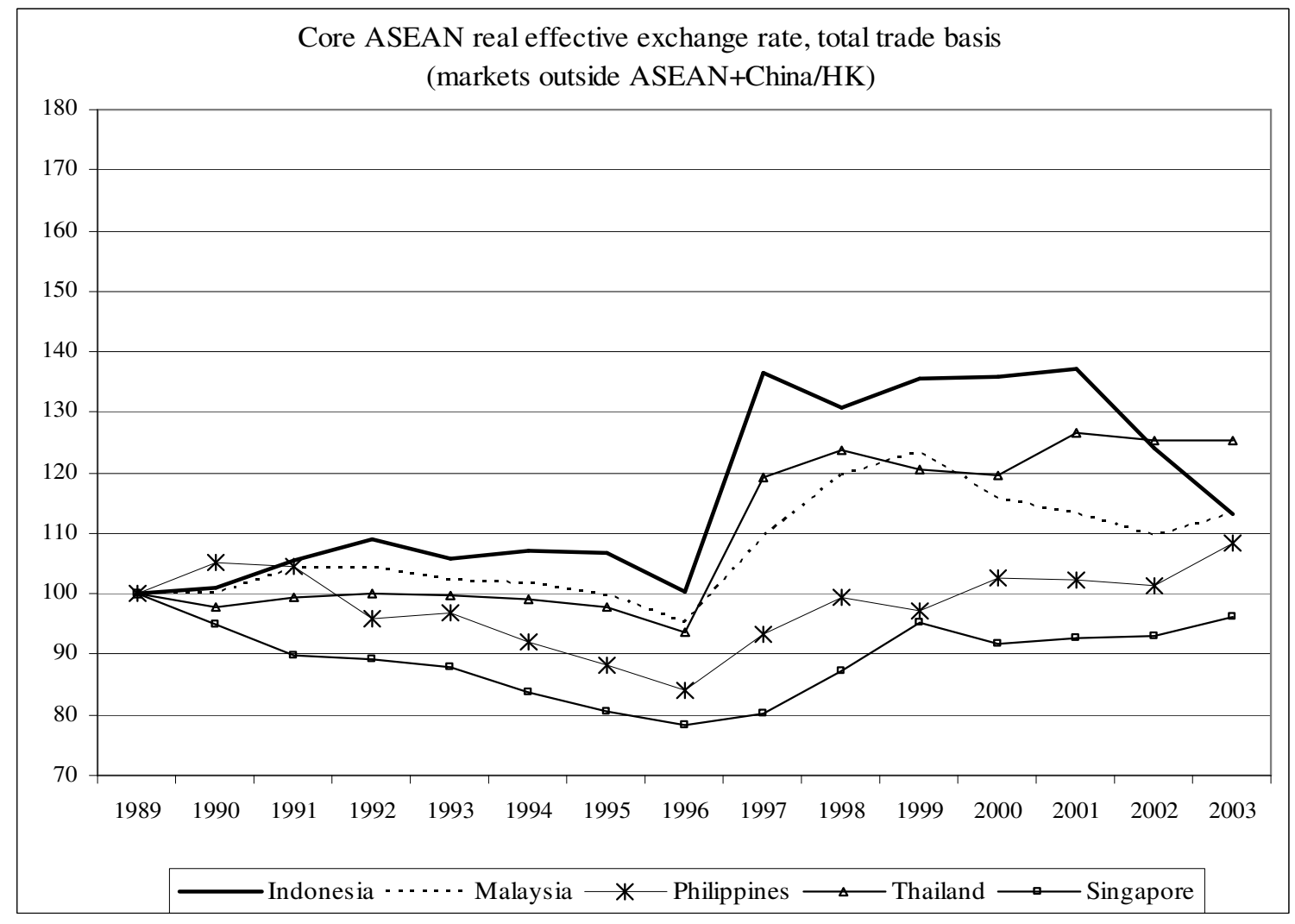

Source: Global Financial data, IMF Direction of Trade Statistics, World Bank WDI 
Table 2.1: External balance, investment, savings and debt for Indonesia, Malaysia and Philippines

\begin{tabular}{|c|c|c|c|c|c|c|c|c|c|c|c|c|c|c|}
\hline & 1990 & 1991 & 1992 & 19993 & 1994 & 1995 & 1996 & 1997 & 1998 & 1999 & 2000 & 2001 & 2002 & 2003 \\
\hline \multicolumn{15}{|l|}{ Indonesia } \\
\hline $\begin{array}{l}\text { Ext. balance, goods } \\
\& \text { services (\% GDP) }\end{array}$ & 1.6 & 1.7 & 2.9 & 3.0 & 1.1 & -1.3 & -0.6 & -0.3 & 9.8 & 8.1 & 9.5 & 7.4 & 6.6 & 5.5 \\
\hline $\begin{array}{l}\text { Gross capital } \\
\text { formation (\% GDP) }\end{array}$ & 30.7 & 31.6 & 30.5 & 29.5 & 31.1 & 31.9 & 30.7 & 31.8 & 16.8 & 11.4 & 16.1 & 17.4 & 15.7 & 16.0 \\
\hline $\begin{array}{l}\text { Gross domestic } \\
\text { savings (\% GDP) }\end{array}$ & 32.3 & 33.2 & 33.4 & 32.5 & 32.2 & 30.6 & 30.1 & 31.5 & 26.5 & 19.5 & 25.6 & 24.9 & 22.2 & 21.5 \\
\hline $\begin{array}{l}\text { External debt, total } \\
(\mathrm{DOD}, \text { current US\$) }\end{array}$ & 69,872 & 79,548 & 88,002 & 89,172 & 107,824 & 124,398 & 128,937 & 136,161 & 151,236 & 151,201 & 144,407 & 134,045 & 131,755 & 134,389 \\
\hline GDP (current US\$) & 114,427 & 128,168 & 139,116 & 158,007 & 176,892 & 202,132 & 227,370 & 215,749 & 95,446 & 140,001 & 150,196 & 143,034 & 172,971 & 208,312 \\
\hline Ext. debt, \% GDP & $61.1 \%$ & $62.1 \%$ & $63.3 \%$ & $56.4 \%$ & $61.0 \%$ & $61.5 \%$ & $56.7 \%$ & $63.1 \%$ & $158.5 \%$ & $108.0 \%$ & $96.1 \%$ & $93.7 \%$ & $76.2 \%$ & $64.5 \%$ \\
\hline \multicolumn{15}{|l|}{ Malaysia } \\
\hline $\begin{array}{l}\text { Ext. balance, goods } \\
\& \text { services (\% GDP) }\end{array}$ & 2.1 & -3.7 & 1.4 & -0.1 & -1.6 & -3.9 & 1.4 & 0.9 & 22.0 & 25.1 & 20.0 & 18.4 & 18.3 & 21.0 \\
\hline $\begin{array}{l}\text { Gross capital } \\
\text { formation }(\% \mathrm{GDP})\end{array}$ & 32.4 & 37.8 & 35.4 & 39.2 & 41.2 & 43.6 & 41.5 & 43.0 & 26.7 & 22.4 & 27.3 & 23.9 & 23.8 & 21.4 \\
\hline $\begin{array}{l}\text { Gross domestic } \\
\text { savings (\% GDP) }\end{array}$ & 34.5 & 34.1 & 36.7 & 39.1 & 39.6 & 39.7 & 42.9 & 43.9 & 48.7 & 47.4 & 47.3 & 42.3 & 42.1 & 42.3 \\
\hline $\begin{array}{l}\text { External debt, total } \\
\text { (DOD, current US\$) }\end{array}$ & 15,328 & 17,080 & 20,018 & 26,149 & 30,336 & 34,343 & 39,673 & 47,228 & 42,409 & 41,903 & 41,941 & 44,612 & 48,833 & 49,074 \\
\hline GDP (current US\$) & 44,024 & 49,134 & 59,151 & 66,894 & 74,481 & 88,832 & 100,852 & 100,169 & 72,175 & 79,148 & 90,320 & 88,001 & 95,164 & 103,737 \\
\hline Ext. debt, \% GDP & $34.8 \%$ & $34.8 \%$ & $33.8 \%$ & $39.1 \%$ & $40.7 \%$ & $38.7 \%$ & $39.3 \%$ & $47.1 \%$ & $58.8 \%$ & $52.9 \%$ & $46.4 \%$ & $50.7 \%$ & $51.3 \%$ & $47.3 \%$ \\
\hline \multicolumn{15}{|l|}{ Philippines } \\
\hline $\begin{array}{l}\text { Ext. balance, goods } \\
\& \text { services (\% GDP) }\end{array}$ & -5.8 & -3.0 & -4.9 & -8.4 & -6.3 & -7.8 & -8.8 & -10.3 & -6.6 & 0.2 & 1.9 & -3.1 & -0.5 & -2.5 \\
\hline $\begin{array}{l}\text { Gross capital } \\
\text { formation ( } \% \mathrm{GDP})\end{array}$ & 24.2 & 20.2 & 21.3 & 24.0 & 24.1 & 22.5 & 24.0 & 24.8 & 20.3 & 18.4 & 21.2 & 20.6 & 19.3 & 18.7 \\
\hline $\begin{array}{l}\text { Gross domestic } \\
\text { savings (\% of GDP) }\end{array}$ & 18.4 & 17.2 & 16.4 & 15.5 & 17.8 & 14.6 & 15.2 & 14.4 & 13.7 & 18.6 & 23.1 & 17.5 & 18.8 & 16.2 \\
\hline $\begin{array}{l}\text { External debt, total } \\
\text { (DOD, current US\$) }\end{array}$ & 30,580 & 32,494 & 33,220 & 36,143 & 40,257 & 39,391 & 44,031 & 50,746 & 53,529 & 58,063 & 60,850 & 58,499 & 60,090 & 62,663 \\
\hline GDP (current US\$) & 44,331 & 45,417 & 52,977 & 54,368 & 64,085 & 74,120 & 82,847 & 82,343 & 65,172 & 76,157 & 75,913 & 72,043 & 77,954 & 80,574 \\
\hline Ext. debt, \% GDP & $69.0 \%$ & $71.5 \%$ & $62.7 \%$ & $66.5 \%$ & $62.8 \%$ & $53.1 \%$ & $53.1 \%$ & $61.6 \%$ & $82.1 \%$ & $76.2 \%$ & $80.2 \%$ & $81.2 \%$ & $77.1 \%$ & $77.8 \%$ \\
\hline
\end{tabular}


Table 2.2: External balance, investment, savings and debt for Singapore and Thailand

\begin{tabular}{|c|c|c|c|c|c|c|c|c|c|c|c|c|c|c|}
\hline & 1990 & 1991 & 1992 & 1993 & 1994 & 1995 & 1996 & 1997 & 1998 & 1999 & 2000 & 2001 & 2002 & 2003 \\
\hline \multicolumn{15}{|l|}{ Singapore } \\
\hline $\begin{array}{l}\text { Ext. balance, goods } \\
\& \text { services (\% GDP) }\end{array}$ & 6.9 & 10.6 & 9.7 & 7.8 & 14.9 & 16.1 & 14.4 & 12.2 & 21.0 & 17.8 & 16.1 & 19.4 & 22.8 & 33.3 \\
\hline $\begin{array}{l}\text { Gross capital } \\
\text { formation (\% GDP) }\end{array}$ & 36.4 & 34.5 & 35.8 & 37.4 & 33.1 & 34.1 & 35.9 & 39.2 & 32.3 & 32.4 & 32.4 & 25.2 & 21.2 & 13.4 \\
\hline $\begin{array}{l}\text { Gross domestic } \\
\text { savings (\% of GDP) }\end{array}$ & 43.3 & 45.1 & 45.5 & 45.2 & 48.0 & 50.2 & 50.3 & 51.4 & 53.3 & 50.3 & 48.5 & 44.6 & 43.9 & 46.7 \\
\hline $\begin{array}{l}\text { External debt, } \\
\text { (current US\$m) }\end{array}$ & 3,772 & 4,369 & 4,582 & 5,524 & 7,594 & 8,368 & 9,802 & 11,803 & 12,093 & 13,701 & 15,623 & 18,361 & 20,657 & 22,218 \\
\hline GDP (current US\$) & 36,901 & 43,191 & 49,863 & 58,355 & 70,610 & 83,933 & 92,221 & 95,395 & 81,911 & 81,381 & 91,476 & 84,871 & 88,275 & 91,342 \\
\hline Ext. debt, \% GDP & $10.2 \%$ & $10.1 \%$ & $9.2 \%$ & $9.5 \%$ & $10.8 \%$ & $10.0 \%$ & $10.6 \%$ & $12.4 \%$ & $14.8 \%$ & $16.8 \%$ & $17.1 \%$ & $21.6 \%$ & $23.4 \%$ & $24.3 \%$ \\
\hline \multicolumn{15}{|l|}{ Thailand } \\
\hline $\begin{array}{l}\text { Ext. balance, goods } \\
\& \text { services (\% GDP) }\end{array}$ & -7.5 & -6.5 & -4.0 & -4.2 & -4.8 & -6.7 & -6.3 & 1.4 & 15.9 & 12.6 & 8.6 & 6.5 & 7.2 & 6.7 \\
\hline $\begin{array}{l}\text { Gross capital } \\
\text { formation }(\% \mathrm{GDP})\end{array}$ & 41.4 & 42.8 & 40.0 & 40.0 & 40.3 & 42.1 & 41.8 & 33.7 & 20.4 & 20.5 & 22.8 & 24.1 & 23.9 & 25.2 \\
\hline $\begin{array}{l}\text { Gross domestic } \\
\text { savings (\% of GDP) }\end{array}$ & 33.8 & 36.3 & 36.0 & 35.8 & 35.4 & 35.4 & 35.5 & 35.1 & 36.3 & 33.1 & 31.4 & 30.6 & 31.1 & 32.0 \\
\hline $\begin{array}{l}\text { External debt, total } \\
\text { (DOD, current US\$) }\end{array}$ & 28,095 & 37,703 & 41,784 & 52,638 & 65,533 & 100,039 & 112,838 & 109,699 & 104,917 & 96,770 & 79,710 & 67,181 & 59,459 & 51,793 \\
\hline GDP (current US\$) & 85,345 & 98,234 & 111,453 & 125,009 & 144,527 & 167,896 & 181,689 & 150,892 & 111,860 & 122,338 & 122,725 & 115,536 & 126,770 & 142,953 \\
\hline Ext. debt, \% GDP & $32.9 \%$ & $38.4 \%$ & $37.5 \%$ & $42.1 \%$ & $45.3 \%$ & $59.6 \%$ & $62.1 \%$ & $72.7 \%$ & $93.8 \%$ & $79.1 \%$ & $64.9 \%$ & $58.1 \%$ & $46.9 \%$ & $36.2 \%$ \\
\hline
\end{tabular}

Source: All World Bank, World Development Indicators except Singapore external debt from Economist data 
Table 2.3: Regional aggregates for $\%$ of poor at $\$ 1$ and $\$ 2$ per day in East Asia 5*

\begin{tabular}{|l|c|c|c|c|c|c|}
\hline & 1990 & 1996 & 1999 & 2000 & 2001 & 2002 \\
\hline$\$ 1$ per day & 15.6 & 6.9 & 9.0 & 8.0 & 7.0 & 6.2 \\
\hline \$2 per day & 53.3 & 38.5 & 46.2 & 44.7 & 42.8 & 41.1 \\
\hline
\end{tabular}

Source: World Bank, East Asia Update, September 2000

Table 3.1: Export distribution by market, ASEAN+1, 2003 data

\begin{tabular}{|c|c|c|c|c|c|c|c|c|c|c|}
\hline & Total & Japan & Korea & $\overline{\mathbf{U S}}$ & $\overline{\mathbf{E U}}$ & Taiwan & Australia & $\overline{\text { ASEAN }}$ & China & Other \\
\hline & $(b n, \$)$ & \multicolumn{9}{|c|}{ Market distribution } \\
\hline Indonesia & 60.995 & $22.3 \%$ & $7.1 \%$ & $12.1 \%$ & $13.1 \%$ & $3.7 \%$ & $2.9 \%$ & $17.6 \%$ & $6.2 \%$ & $15.0 \%$ \\
\hline Malaysia & 104.966 & $10.7 \%$ & $2.9 \%$ & $19.6 \%$ & $12.1 \%$ & $3.6 \%$ & $2.5 \%$ & $24.8 \%$ & $6.5 \%$ & $17.3 \%$ \\
\hline Philippines & 36.225 & $15.9 \%$ & $3.6 \%$ & $20.1 \%$ & $16.3 \%$ & $6.9 \%$ & $0.9 \%$ & $18.2 \%$ & $5.9 \%$ & $12.3 \%$ \\
\hline Thailand & 80.521 & $14.2 \%$ & $2.0 \%$ & $17.0 \%$ & $14.7 \%$ & $3.2 \%$ & $2.7 \%$ & $20.6 \%$ & $7.1 \%$ & $18.5 \%$ \\
\hline Singapore & 144.121 & $6.7 \%$ & $4.2 \%$ & $14.3 \%$ & $13.4 \%$ & $4.8 \%$ & $3.2 \%$ & $27.9 \%$ & $7.0 \%$ & $18.4 \%$ \\
\hline China & 438.25 & $13.6 \%$ & $4.6 \%$ & $21.1 \%$ & $16.5 \%$ & $2.1 \%$ & $1.4 \%$ & $7.1 \%$ & & $33.7 \%$ \\
\hline China $+H K$ & 490.358 & $14.6 \%$ & $5.0 \%$ & $27.4 \%$ & $20.8 \%$ & $2.9 \%$ & $1.8 \%$ & $9.1 \%$ & & $18.3 \%$ \\
\hline Core ASEAN & 426.828 & & & & & & & & & \\
\hline
\end{tabular}

Source: IMF DOTS 2004 Yearbook

Table 3.2: Import distribution by market, ASEAN+1, 2003 data

\begin{tabular}{|c|c|c|c|c|c|c|c|c|c|c|}
\hline & Total & Japan & Korea & $\mathbf{U S}$ & $\mathbf{E U}$ & Taiwan & Australia & ASEAN & China & Other \\
\hline & $(b n, \$)$ & \multicolumn{9}{|c|}{ Source distribution } \\
\hline Indonesia & 32.544 & $13.0 \%$ & $4.7 \%$ & $8.3 \%$ & $10.9 \%$ & $2.7 \%$ & $5.1 \%$ & $23.8 \%$ & $9.1 \%$ & $22.5 \%$ \\
\hline Malaysia & 82.726 & $17.3 \%$ & $5.5 \%$ & $15.5 \%$ & $11.8 \%$ & $5.0 \%$ & $1.5 \%$ & $24.4 \%$ & $8.8 \%$ & $10.1 \%$ \\
\hline Philippines & 37.5 & $20.4 \%$ & $6.4 \%$ & $19.8 \%$ & $8.0 \%$ & $5.0 \%$ & $1.3 \%$ & $17.1 \%$ & $4.8 \%$ & $17.3 \%$ \\
\hline Thailand & 75.809 & $24.1 \%$ & $3.9 \%$ & $9.5 \%$ & $10.0 \%$ & $4.3 \%$ & $2.1 \%$ & $16.6 \%$ & $8.0 \%$ & $21.6 \%$ \\
\hline Singapore & 127.996 & $12.5 \%$ & $3.7 \%$ & $14.1 \%$ & $12.5 \%$ & $5.1 \%$ & $1.7 \%$ & $28.6 \%$ & $8.7 \%$ & $13.3 \%$ \\
\hline China & 412.836 & $18.0 \%$ & $10.4 \%$ & $8.2 \%$ & $12.9 \%$ & $12.0 \%$ & $1.8 \%$ & $11.5 \%$ & & $25.3 \%$ \\
\hline China $+H K$ & 533.002 & $19.1 \%$ & $10.2 \%$ & $8.8 \%$ & $13.6 \%$ & $12.3 \%$ & $1.7 \%$ & $14.0 \%$ & & $20.4 \%$ \\
\hline Core ASEAN & 356.575 & & & & & & & & & \\
\hline
\end{tabular}


Table 3.3: Commodity exports to the world, \% of total exports for each sector by country, 2002

\begin{tabular}{|c|c|c|c|c|c|c|c|c|c|c|c|c|}
\hline SIC code & Core ASI & AN count & & & & Other A & EAN & & & & China & \\
\hline & Indonesia & Malaysia & Philippines & Thailand & Sing. & Vietnam & Myanmar & Cambodia & Laos & Brunei & China & China+HK \\
\hline Total, \$ bn & 61.264 & 101.797 & 38.176 & 75.043 & 127.894 & 16.847 & 2.639 & 1.909 & 0.330 & 4.074 & 358.565 & 564.977 \\
\hline 0-Food & $6.3 \%$ & $2.1 \%$ & $3.9 \%$ & $12.3 \%$ & $1.5 \%$ & $17.4 \%$ & $21.5 \%$ & $0.8 \%$ & $4.7 \%$ & $0.0 \%$ & $4.4 \%$ & $3.2 \%$ \\
\hline 1-Beverages & $0.5 \%$ & $0.3 \%$ & $0.2 \%$ & $0.2 \%$ & $0.8 \%$ & $0.1 \%$ & $0.5 \%$ & $0.1 \%$ & $0.0 \%$ & $0.0 \%$ & $0.3 \%$ & $0.3 \%$ \\
\hline 2-Crude materials & $8.0 \%$ & $2.3 \%$ & $0.9 \%$ & $3.9 \%$ & $0.6 \%$ & $2.4 \%$ & $12.6 \%$ & $1.4 \%$ & $4.6 \%$ & $0.0 \%$ & $1.4 \%$ & $1.2 \%$ \\
\hline 3-Fuels, lubricants \& related materials & $24.4 \%$ & $8.5 \%$ & $1.1 \%$ & $2.1 \%$ & $6.9 \%$ & $19.2 \%$ & $1.1 \%$ & $0.0 \%$ & $0.0 \%$ & $88.2 \%$ & $2.6 \%$ & $1.7 \%$ \\
\hline $\begin{array}{l}\text { 4-Animal \& vegetable oils, fats } \& \\
\text { waxes }\end{array}$ & $4.6 \%$ & $5.0 \%$ & $1.0 \%$ & $0.1 \%$ & $0.2 \%$ & $0.0 \%$ & $0.1 \%$ & $0.0 \%$ & $0.0 \%$ & $0.0 \%$ & $0.0 \%$ & $0.0 \%$ \\
\hline 5-Chemicals \& related products, n.e.s. & $5.2 \%$ & $4.6 \%$ & $1.0 \%$ & $5.2 \%$ & $8.7 \%$ & $1.1 \%$ & $0.1 \%$ & $0.0 \%$ & $0.0 \%$ & $0.0 \%$ & $4.6 \%$ & $4.6 \%$ \\
\hline $\begin{array}{l}\text { 6-Manufactured goods classified } \\
\text { chiefly by material }\end{array}$ & $19.2 \%$ & $7.0 \%$ & $2.9 \%$ & $10.2 \%$ & $3.7 \%$ & $5.3 \%$ & $2.6 \%$ & $2.3 \%$ & $0.7 \%$ & $1.1 \%$ & $16.4 \%$ & $15.4 \%$ \\
\hline 7-Machinery \& transport equipment & $16.8 \%$ & $60.3 \%$ & $39.7 \%$ & $39.9 \%$ & $64.5 \%$ & $7.1 \%$ & $1.1 \%$ & $0.2 \%$ & $0.1 \%$ & $4.4 \%$ & $38.6 \%$ & $40.2 \%$ \\
\hline 8-Miscellaneous manufactured articles & $14.5 \%$ & $8.6 \%$ & $7.0 \%$ & $15.6 \%$ & $8.9 \%$ & $39.7 \%$ & $27.9 \%$ & $93.6 \%$ & $40.4 \%$ & $6.1 \%$ & $31.6 \%$ & $32.8 \%$ \\
\hline $\begin{array}{l}\text { 9-Commodities \& trans. not classified } \\
\text { elsewhere }\end{array}$ & $0.6 \%$ & $1.2 \%$ & $42.3 \%$ & $10.6 \%$ & $4.2 \%$ & $7.6 \%$ & $32.6 \%$ & $1.6 \%$ & $49.5 \%$ & $0.2 \%$ & $0.2 \%$ & $0.5 \%$ \\
\hline
\end{tabular}


Table 3.4: Commodity imports from the world, \% of total imports for each sector by country, 2002

\begin{tabular}{|c|c|c|c|c|c|c|c|c|c|c|c|c|}
\hline SIC code & Core ASE & AN count & & & & Other $A_{i}$ & EAN & & & & China & \\
\hline & Indonesia & Malaysia & Philippines & Thailand & Sing. & Vietnam & Myanmar & Cambodia & Laos & Brunei & China & China+HK \\
\hline Total, \$ bn & 28.143 & 84.884 & 30.682 & 53.332 & 114.596 & 15.443 & 2.245 & 1.546 & 0.186 & 1.884 & 328.045 & 510.141 \\
\hline 0-Food & $11.1 \%$ & $4.0 \%$ & $7.8 \%$ & $3.5 \%$ & $2.6 \%$ & $5.1 \%$ & $5.4 \%$ & $1.5 \%$ & $3.3 \%$ & $9.2 \%$ & $1.7 \%$ & $2.3 \%$ \\
\hline 1-Beverages & $0.8 \%$ & $0.5 \%$ & $2.0 \%$ & $0.5 \%$ & $0.7 \%$ & $2.3 \%$ & $2.7 \%$ & $8.9 \%$ & $16.7 \%$ & $2.5 \%$ & $0.1 \%$ & $0.3 \%$ \\
\hline 2-Crude materials & $8.6 \%$ & $1.9 \%$ & $2.5 \%$ & $3.5 \%$ & $0.6 \%$ & $2.2 \%$ & $0.8 \%$ & $2.1 \%$ & $0.3 \%$ & $0.5 \%$ & $6.6 \%$ & $4.7 \%$ \\
\hline 3-Fuels, lubricants \& related materials & $12.8 \%$ & $4.1 \%$ & $7.6 \%$ & $4.7 \%$ & $10.7 \%$ & $8.7 \%$ & $16.1 \%$ & $8.8 \%$ & $6.7 \%$ & $1.4 \%$ & $5.1 \%$ & $4.1 \%$ \\
\hline $\begin{array}{l}\text { 4-Animal \& vegetable oils, fats \& } \\
\text { waxes }\end{array}$ & $0.2 \%$ & $0.4 \%$ & $0.2 \%$ & $0.1 \%$ & $0.3 \%$ & $0.5 \%$ & $2.5 \%$ & $0.4 \%$ & $0.0 \%$ & $0.3 \%$ & $0.6 \%$ & $0.4 \%$ \\
\hline 5-Chemicals \& related products, n.e.s. & $14.6 \%$ & $6.3 \%$ & $8.3 \%$ & $10.8 \%$ & $5.5 \%$ & $13.6 \%$ & $9.3 \%$ & $5.0 \%$ & $3.6 \%$ & $4.4 \%$ & $12.3 \%$ & $10.2 \%$ \\
\hline $\begin{array}{l}\text { 6-Manufactured goods classified } \\
\text { chiefly by material }\end{array}$ & $16.7 \%$ & $9.6 \%$ & $11.9 \%$ & $16.4 \%$ & $7.7 \%$ & $26.7 \%$ & $24.6 \%$ & $44.8 \%$ & $14.7 \%$ & $20.5 \%$ & $17.8 \%$ & $18.1 \%$ \\
\hline 7-Machinery \& transport equipment & $29.8 \%$ & $63.3 \%$ & $48.0 \%$ & $49.9 \%$ & $57.9 \%$ & $33.4 \%$ & $30.5 \%$ & $17.8 \%$ & $40.9 \%$ & $46.9 \%$ & $46.7 \%$ & $46.8 \%$ \\
\hline 8-Miscellaneous manufactured articles & $3.6 \%$ & $6.1 \%$ & $5.2 \%$ & $6.6 \%$ & $8.9 \%$ & $6.0 \%$ & $5.5 \%$ & $8.9 \%$ & $5.5 \%$ & $10.7 \%$ & $7.6 \%$ & $11.1 \%$ \\
\hline $\begin{array}{l}\text { 9-Commodities \& trans. not classified } \\
\text { elsewhere }\end{array}$ & $1.8 \%$ & $3.9 \%$ & $6.5 \%$ & $4.0 \%$ & $5.0 \%$ & $1.5 \%$ & $2.6 \%$ & $1.8 \%$ & $8.2 \%$ & $3.7 \%$ & $1.6 \%$ & $1.9 \%$ \\
\hline
\end{tabular}

Source: World Trade Analyzer, Statistics Canada. International Trade Division 
Table 3.5: Breakdown of key sectors for commodity exports and imports, extracted from tables A3.3 and A3.4, \%, 2002

\begin{tabular}{|c|c|c|c|c|c|c|c|c|c|c|c|c|}
\hline \multirow{2}{*}{$\begin{array}{l}\text { SIC code } \\
\text { EXPORTS } \\
\end{array}$} & \multicolumn{5}{|c|}{ Core ASEAN countries } & \multicolumn{5}{|c|}{ Other ASEAN } & \multicolumn{2}{|l|}{ China } \\
\hline & Indonesia & Malaysia & Philipp. & Thai. & Sing. & Vietnam & Myanmar & Camb. & Laos & Brunei & China & China+HK \\
\hline 6-Manufactured goods classified chiefly by material & $19.2 \%$ & $7.0 \%$ & $2.9 \%$ & $10.2 \%$ & $3.7 \%$ & $5.3 \%$ & $2.6 \%$ & $2.3 \%$ & $0.7 \%$ & $1.1 \%$ & $15.4 \%$ & $15.0 \%$ \\
\hline 65X-Textile yarn,fabrics,made-upart.,related products & $5.1 \%$ & $1.1 \%$ & $0.7 \%$ & $2.1 \%$ & $0.6 \%$ & $1.8 \%$ & $0.4 \%$ & $1.3 \%$ & $0.1 \%$ & $0.6 \%$ & $6.1 \%$ & $6.1 \%$ \\
\hline 7-Machinery and transport equipment & $16.8 \%$ & $60.3 \%$ & $39.7 \%$ & $39.9 \%$ & $64.5 \%$ & $7.1 \%$ & $1.1 \%$ & $0.2 \%$ & $0.1 \%$ & $4.4 \%$ & $44.0 \%$ & $43.8 \%$ \\
\hline $75 \mathrm{X}$-Office mach. \& automatic data processing equip. & $3.8 \%$ & $19.1 \%$ & $17.1 \%$ & $12.3 \%$ & $21.0 \%$ & $0.5 \%$ & $0.0 \%$ & $0.0 \%$ & $0.0 \%$ & $0.0 \%$ & $12.2 \%$ & $11.7 \%$ \\
\hline 76X-Telecommunic. \& sound recording apparatus & $5.9 \%$ & $11.4 \%$ & $3.0 \%$ & $6.7 \%$ & $6.4 \%$ & $0.7 \%$ & $0.1 \%$ & $0.0 \%$ & $0.0 \%$ & $0.1 \%$ & $9.2 \%$ & $9.6 \%$ \\
\hline 77X-Elec. machinery,apparatus \& appliances n.e.s. & $4.1 \%$ & $25.9 \%$ & $16.4 \%$ & $11.7 \%$ & $29.8 \%$ & $3.6 \%$ & $0.3 \%$ & $0.1 \%$ & $0.0 \%$ & $0.1 \%$ & $15.1 \%$ & $15.5 \%$ \\
\hline 8-Miscellaneous manufactured articles & $14.5 \%$ & $8.6 \%$ & $7.0 \%$ & $15.6 \%$ & $8.9 \%$ & $39.7 \%$ & $27.9 \%$ & $93.6 \%$ & $40.4 \%$ & $6.1 \%$ & $27.9 \%$ & $29.4 \%$ \\
\hline 84X-Articles of apparel and clothing accessories & $7.1 \%$ & $2.1 \%$ & $3.9 \%$ & $5.4 \%$ & $1.4 \%$ & $14.6 \%$ & $26.1 \%$ & $85.6 \%$ & $38.9 \%$ & $5.9 \%$ & $9.8 \%$ & $8.1 \%$ \\
\hline 851-Footwear & $2.0 \%$ & $0.1 \%$ & $0.1 \%$ & $1.2 \%$ & $0.1 \%$ & $16.9 \%$ & $0.8 \%$ & $7.5 \%$ & $1.3 \%$ & $0.0 \%$ & $2.4 \%$ & $4.4 \%$ \\
\hline IMPORTS & & & & & & & & & & & & \\
\hline 6-Manufactured goods classified chiefly by material & $16.7 \%$ & $9.6 \%$ & $11.9 \%$ & $16.4 \%$ & $7.7 \%$ & $26.7 \%$ & $24.6 \%$ & $44.8 \%$ & $14.7 \%$ & $20.5 \%$ & $16.5 \%$ & $17.0 \%$ \\
\hline 65X-Textile yarn,fabrics,made-upart.,related products & $5.0 \%$ & $1.4 \%$ & $3.6 \%$ & $2.3 \%$ & $0.9 \%$ & $9.3 \%$ & $12.1 \%$ & $36.7 \%$ & $8.8 \%$ & $8.3 \%$ & $5.0 \%$ & $5.4 \%$ \\
\hline 7-Machinery and transport equipment & $29.8 \%$ & $63.3 \%$ & $48.0 \%$ & $49.9 \%$ & $57.9 \%$ & $33.4 \%$ & $30.5 \%$ & $17.8 \%$ & $40.9 \%$ & $46.9 \%$ & $45.5 \%$ & $45.9 \%$ \\
\hline 77X-Elec. machinery,apparatus \& appliances n.e.s. & $3.2 \%$ & $37.4 \%$ & $22.9 \%$ & $17.6 \%$ & $24.5 \%$ & $5.9 \%$ & $3.4 \%$ & $1.1 \%$ & $5.1 \%$ & $4.6 \%$ & $18.2 \%$ & $18.4 \%$ \\
\hline
\end{tabular}


Table 3.6: SIC-6, Manufactured goods classified chiefly by material export shares to markets outside core ASEAN+1 countries

\begin{tabular}{||l|r|r|r|r|r|r|r|r||}
\hline \hline & \multicolumn{1}{|c|}{ Total } & \multicolumn{1}{c|}{ Japan } & \multicolumn{1}{c|}{ Korea } & \multicolumn{1}{c|}{ U.S. } & \multicolumn{1}{c|}{ Europe } & Taiwan & Australia & Other \\
\hline Indonesia & $19.2 \%$ & $16.3 \%$ & $15.2 \%$ & $13.3 \%$ & $18.3 \%$ & $19.2 \%$ & $19.0 \%$ & $25.0 \%$ \\
\hline Malaysia & $7.0 \%$ & $9.1 \%$ & $9.7 \%$ & $2.6 \%$ & $6.0 \%$ & $7.9 \%$ & $10.0 \%$ & $8.3 \%$ \\
\hline Philippines & $2.9 \%$ & $3.4 \%$ & $6.8 \%$ & $2.3 \%$ & $1.5 \%$ & $1.5 \%$ & $5.9 \%$ & $3.7 \%$ \\
\hline Thailand & $10.2 \%$ & $8.7 \%$ & $14.5 \%$ & $11.3 \%$ & $11.7 \%$ & $13.1 \%$ & $13.1 \%$ & $8.8 \%$ \\
\hline Singapore & $3.7 \%$ & $1.9 \%$ & $3.1 \%$ & $0.6 \%$ & $1.9 \%$ & $3.4 \%$ & $4.1 \%$ & $5.4 \%$ \\
\hline & & & & & & & & \\
\hline China & $16.4 \%$ & $12.2 \%$ & $22.9 \%$ & $13.2 \%$ & $13.8 \%$ & $17.2 \%$ & $19.1 \%$ & $20.4 \%$ \\
\hline China+Hong Kong & $15.4 \%$ & $11.1 \%$ & $18.8 \%$ & $11.1 \%$ & $11.3 \%$ & $12.2 \%$ & $16.4 \%$ & $20.2 \%$ \\
\hline
\end{tabular}

Source: World Trade Analyzer, Statistics Canada. International Trade Division

Table 3.7: SIC-7, Machinery and transport equipment export shares to markets outside core ASEAN+1 countries

\begin{tabular}{||l|r|r|r|r|r|r|r|r||}
\hline \hline & Total & Japan & \multicolumn{1}{|c|}{ Korea } & U.S. & Europe & Taiwan & Australia & Other \\
\hline Indonesia & $16.8 \%$ & $11.6 \%$ & $6.2 \%$ & $19.2 \%$ & $18.3 \%$ & $7.4 \%$ & $10.4 \%$ & $22.6 \%$ \\
\hline Malaysia & $60.3 \%$ & $42.9 \%$ & $48.1 \%$ & $80.6 \%$ & $62.9 \%$ & $64.7 \%$ & $38.3 \%$ & $56.0 \%$ \\
\hline Philippines & $39.7 \%$ & $53.2 \%$ & $26.7 \%$ & $33.5 \%$ & $54.9 \%$ & $33.1 \%$ & $58.3 \%$ & $31.3 \%$ \\
\hline Thailand & $39.9 \%$ & $39.4 \%$ & $43.7 \%$ & $39.4 \%$ & $45.8 \%$ & $55.3 \%$ & $44.2 \%$ & $36.4 \%$ \\
\hline Singapore & $64.5 \%$ & $59.5 \%$ & $71.9 \%$ & $75.7 \%$ & $71.4 \%$ & $75.2 \%$ & $47.2 \%$ & $59.1 \%$ \\
\hline & & & & & & & & \\
\hline China & $38.6 \%$ & $32.4 \%$ & $30.6 \%$ & $39.4 \%$ & $40.0 \%$ & $50.3 \%$ & $32.2 \%$ & $40.7 \%$ \\
\hline China+Hong Kong & $40.2 \%$ & $33.7 \%$ & $37.4 \%$ & $35.5 \%$ & $38.3 \%$ & $55.9 \%$ & $32.1 \%$ & $44.9 \%$ \\
\hline
\end{tabular}

Source: World Trade Analyzer, Statistics Canada. International Trade Division

Table 3.8: SIC-8, Miscellaneous manufactured articles export shares to markets outside core ASEAN+1 countries

\begin{tabular}{|l|r|r|r|r|r|r|r|r||}
\hline & \multicolumn{1}{|c|}{ Total } & \multicolumn{1}{c|}{ Japan } & \multicolumn{1}{|c|}{ Korea } & U.S. & Europe & Taiwan & Australia & Other \\
\hline Indonesia & $14.5 \%$ & $5.6 \%$ & $1.9 \%$ & $43.6 \%$ & $29.0 \%$ & $2.1 \%$ & $7.0 \%$ & $7.2 \%$ \\
\hline Malaysia & $8.6 \%$ & $7.5 \%$ & $2.4 \%$ & $12.0 \%$ & $14.0 \%$ & $3.6 \%$ & $12.6 \%$ & $6.6 \%$ \\
\hline Philippines & $7.0 \%$ & $3.7 \%$ & $0.9 \%$ & $18.1 \%$ & $6.1 \%$ & $0.6 \%$ & $8.3 \%$ & $2.2 \%$ \\
\hline Thailand & $15.6 \%$ & $14.8 \%$ & $5.8 \%$ & $31.9 \%$ & $26.5 \%$ & $3.4 \%$ & $11.3 \%$ & $4.6 \%$ \\
\hline Singapore & $8.9 \%$ & $19.1 \%$ & $9.1 \%$ & $11.0 \%$ & $7.9 \%$ & $5.2 \%$ & $12.3 \%$ & $7.5 \%$ \\
\hline & & & & & & & & \\
\hline China & $31.6 \%$ & $35.6 \%$ & $16.5 \%$ & $41.2 \%$ & $35.7 \%$ & $12.9 \%$ & $38.1 \%$ & $24.5 \%$ \\
\hline China+Hong Kong & $32.8 \%$ & $38.3 \%$ & $17.6 \%$ & $49.0 \%$ & $42.2 \%$ & $16.8 \%$ & $42.6 \%$ & $20.8 \%$ \\
\hline
\end{tabular}


Table 3.9: SIC-6, Manufactured good import shares by source, outside core ASEAN+1 countries

\begin{tabular}{|l|r|r|r|r|r|r|r|r||}
\hline & \multicolumn{1}{|c|}{ Total } & \multicolumn{1}{c|}{ Japan } & Korea & U.S. & Europe & Taiwan & Australia & Other \\
\hline Indonesia & $16.7 \%$ & $19.5 \%$ & $36.3 \%$ & $7.0 \%$ & $12.0 \%$ & $36.6 \%$ & $15.5 \%$ & $14.2 \%$ \\
\hline Malaysia & $9.6 \%$ & $15.0 \%$ & $13.7 \%$ & $3.0 \%$ & $9.0 \%$ & $13.1 \%$ & $26.7 \%$ & $8.8 \%$ \\
\hline Philippines & $11.9 \%$ & $11.2 \%$ & $17.0 \%$ & $3.0 \%$ & $11.4 \%$ & $18.8 \%$ & $13.3 \%$ & $13.1 \%$ \\
\hline Thailand & $16.4 \%$ & $18.7 \%$ & $21.5 \%$ & $7.6 \%$ & $16.6 \%$ & $28.0 \%$ & $26.1 \%$ & $14.1 \%$ \\
\hline Singapore & $7.7 \%$ & $9.0 \%$ & $9.2 \%$ & $3.8 \%$ & $9.9 \%$ & $6.9 \%$ & $5.4 \%$ & $7.9 \%$ \\
\hline & & & & & & & & \\
\hline China & $17.8 \%$ & $18.5 \%$ & $24.8 \%$ & $6.0 \%$ & $12.7 \%$ & $24.6 \%$ & $17.8 \%$ & $18.0 \%$ \\
\hline China+Hong Kong & $18.1 \%$ & $16.4 \%$ & $24.3 \%$ & $7.6 \%$ & $16.3 \%$ & $22.8 \%$ & $18.4 \%$ & $18.8 \%$ \\
\hline
\end{tabular}

Source: World Trade Analyzer, Statistics Canada. International Trade Division

Table 3.10: SIC-7, Machinery and transport equipment import shares by source, outside core ASEAN+1 countries

\begin{tabular}{||l|c|c|c|c|r|r|r|r||}
\hline \hline & Total & Japan & \multicolumn{1}{|c|}{ Korea } & U.S. & Europe & Taiwan & Australia & Other \\
\hline Indonesia & $29.8 \%$ & $56.6 \%$ & $24.0 \%$ & $35.7 \%$ & $44.5 \%$ & $29.5 \%$ & $13.6 \%$ & $15.9 \%$ \\
\hline Malaysia & $63.3 \%$ & $64.6 \%$ & $75.1 \%$ & $79.4 \%$ & $65.1 \%$ & $72.0 \%$ & $13.0 \%$ & $56.8 \%$ \\
\hline Philippines & $48.0 \%$ & $66.2 \%$ & $59.9 \%$ & $66.1 \%$ & $49.5 \%$ & $27.2 \%$ & $6.9 \%$ & $36.0 \%$ \\
\hline Thailand & $49.9 \%$ & $60.9 \%$ & $57.9 \%$ & $51.2 \%$ & $46.3 \%$ & $46.3 \%$ & $5.8 \%$ & $45.6 \%$ \\
\hline Singapore & $57.9 \%$ & $64.2 \%$ & $71.6 \%$ & $66.4 \%$ & $55.7 \%$ & $80.2 \%$ & $13.0 \%$ & $53.1 \%$ \\
\hline & & & & & & & & \\
\hline China & $46.7 \%$ & $54.2 \%$ & $43.5 \%$ & $54.3 \%$ & $60.6 \%$ & $47.5 \%$ & $5.2 \%$ & $40.4 \%$ \\
\hline China+Hong Kong & $46.8 \%$ & $55.4 \%$ & $46.4 \%$ & $52.2 \%$ & $52.8 \%$ & $51.6 \%$ & $6.6 \%$ & $41.9 \%$ \\
\hline
\end{tabular}

Source: World Trade Analyzer, Statistics Canada. International Trade Division

Table 3.11: SIC-8, Miscellaneous manufactured article import shares by source, outside core ASEAN+1 countries

\begin{tabular}{||l|r|r|r|r|r|r|r|r||}
\hline \hline & Total & \multicolumn{1}{c|}{ Japan } & \multicolumn{1}{c|}{ Korea } & \multicolumn{1}{c|}{ U.S. } & Europe & Taiwan & Australia & Other \\
\hline Indonesia & $3.6 \%$ & $3.7 \%$ & $5.4 \%$ & $2.7 \%$ & $3.5 \%$ & $4.1 \%$ & $1.3 \%$ & $3.8 \%$ \\
\hline Malaysia & $6.1 \%$ & $7.3 \%$ & $2.0 \%$ & $6.4 \%$ & $6.6 \%$ & $4.3 \%$ & $3.6 \%$ & $6.1 \%$ \\
\hline Philippines & $5.2 \%$ & $4.4 \%$ & $2.6 \%$ & $4.3 \%$ & $6.2 \%$ & $3.4 \%$ & $3.9 \%$ & $6.4 \%$ \\
\hline Thailand & $6.6 \%$ & $6.5 \%$ & $2.9 \%$ & $8.7 \%$ & $10.3 \%$ & $7.6 \%$ & $2.7 \%$ & $5.3 \%$ \\
\hline Singapore & $8.9 \%$ & $8.2 \%$ & $3.1 \%$ & $11.2 \%$ & $12.3 \%$ & $5.0 \%$ & $5.4 \%$ & $8.5 \%$ \\
\hline & & & & & & & & \\
\hline China & $7.6 \%$ & $8.7 \%$ & $4.7 \%$ & $9.0 \%$ & $7.7 \%$ & $8.7 \%$ & $2.6 \%$ & $7.3 \%$ \\
\hline China+Hong Kong & $11.1 \%$ & $10.2 \%$ & $4.6 \%$ & $10.6 \%$ & $12.4 \%$ & $7.9 \%$ & $4.8 \%$ & $13.1 \%$ \\
\hline
\end{tabular}


Table 4.1: Export shares for weighting real effective exchange rates

\begin{tabular}{|c|c|c|c|c|c|c|c|}
\hline & Japan & Korea, Rep. & United States & $E U$ & Taiwan & Australia & \\
\hline Indonesia & $36.5 \%$ & $11.6 \%$ & $19.8 \%$ & $21.4 \%$ & $6.0 \%$ & $4.8 \%$ & $100.0 \%$ \\
\hline Malaysia & $20.8 \%$ & $5.6 \%$ & $38.1 \%$ & $23.6 \%$ & $7.0 \%$ & $4.8 \%$ & $100.0 \%$ \\
\hline Philippines & $25.0 \%$ & $5.7 \%$ & $31.6 \%$ & $25.5 \%$ & $10.8 \%$ & $1.4 \%$ & $100.0 \%$ \\
\hline Thailand & $26.4 \%$ & $3.7 \%$ & $31.6 \%$ & $27.3 \%$ & $6.0 \%$ & $5.0 \%$ & $100.0 \%$ \\
\hline Singapore & $14.4 \%$ & $9.0 \%$ & $30.6 \%$ & $28.7 \%$ & $10.3 \%$ & $7.0 \%$ & $100.0 \%$ \\
\hline China & $22.9 \%$ & $7.7 \%$ & $35.7 \%$ & $27.8 \%$ & $3.5 \%$ & $2.4 \%$ & $100.0 \%$ \\
\hline China+HK & $20.1 \%$ & $6.9 \%$ & $37.8 \%$ & $28.6 \%$ & $4.1 \%$ & $2.5 \%$ & $100.0 \%$ \\
\hline
\end{tabular}

Source: World Trade Analyzer, Statistics Canada. International Trade Division

Table 4.2: Import shares for weighting real effective exchange rates

\begin{tabular}{||l|c|c|c|c|c|c|c||}
\hline \hline & Japan & Korea, Rep. & United States & EU & Taiwan & Australia & \\
\hline Indonesia & $29.1 \%$ & $10.5 \%$ & $18.6 \%$ & $24.5 \%$ & $6.0 \%$ & $11.3 \%$ & $100.0 \%$ \\
\hline Malaysia & $30.5 \%$ & $9.7 \%$ & $27.4 \%$ & $20.9 \%$ & $8.8 \%$ & $2.7 \%$ & $100.0 \%$ \\
\hline Philippines & $33.5 \%$ & $10.5 \%$ & $32.5 \%$ & $13.2 \%$ & $8.2 \%$ & $2.2 \%$ & $100.0 \%$ \\
\hline Thailand & $44.8 \%$ & $7.2 \%$ & $17.6 \%$ & $18.6 \%$ & $7.9 \%$ & $3.9 \%$ & $100.0 \%$ \\
\hline Singapore & $25.2 \%$ & $7.4 \%$ & $28.5 \%$ & $25.2 \%$ & $10.2 \%$ & $3.5 \%$ & $100.0 \%$ \\
\hline & & & & & & & \\
\hline China & $28.4 \%$ & $16.5 \%$ & $13.0 \%$ & $20.3 \%$ & $18.9 \%$ & $2.8 \%$ & $100.0 \%$ \\
\hline China+HK & $29.1 \%$ & $15.5 \%$ & $13.4 \%$ & $20.7 \%$ & $18.7 \%$ & $2.5 \%$ & $100.0 \%$ \\
\hline \hline
\end{tabular}

Source: World Trade Analyzer, Statistics Canada. International Trade Division

Table 4.3: Trade shares for weighting real effective exchange rates

\begin{tabular}{||l|c|c|c|c|c|c|c||}
\hline \hline & \multicolumn{5}{|c|}{} & & \\
\hline & Japan & Korea, Rep. & United States & EU & Taiwan & Australia & check \\
\hline Indonesia & $34.4 \%$ & $11.3 \%$ & $19.5 \%$ & $22.2 \%$ & $6.0 \%$ & $6.6 \%$ & $100.0 \%$ \\
\hline Malaysia & $25.3 \%$ & $7.5 \%$ & $33.1 \%$ & $22.3 \%$ & $7.8 \%$ & $3.8 \%$ & $100.0 \%$ \\
\hline Philippines & $29.2 \%$ & $8.1 \%$ & $32.0 \%$ & $19.4 \%$ & $9.5 \%$ & $1.8 \%$ & $100.0 \%$ \\
\hline Thailand & $35.3 \%$ & $5.4 \%$ & $24.8 \%$ & $23.1 \%$ & $6.9 \%$ & $4.5 \%$ & $100.0 \%$ \\
\hline Singapore & $19.6 \%$ & $8.2 \%$ & $29.6 \%$ & $27.0 \%$ & $10.2 \%$ & $5.3 \%$ & $100.0 \%$ \\
\hline & & & & & & & \\
\hline China & $22.9 \%$ & $7.7 \%$ & $35.7 \%$ & $27.8 \%$ & $3.5 \%$ & $2.4 \%$ & $100.0 \%$ \\
\hline China+HK & $24.5 \%$ & $11.2 \%$ & $25.7 \%$ & $24.7 \%$ & $11.3 \%$ & $2.5 \%$ & $100.0 \%$ \\
\hline \hline
\end{tabular}

Source: World Trade Analyzer, Statistics Canada. International Trade Division 
Graph 4.1: Real effective exchange rate, export basis

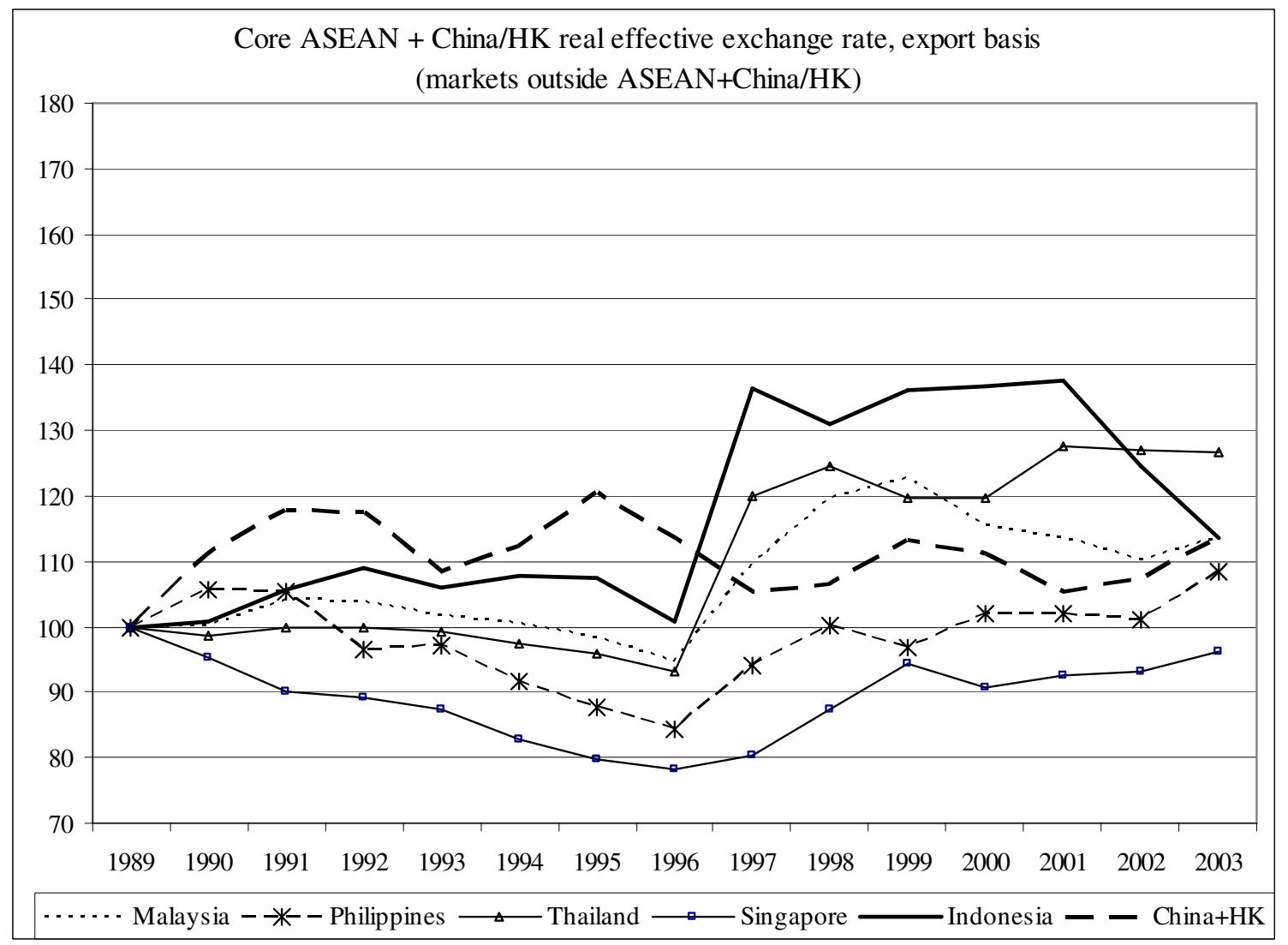

Source: Global Financial data, IMF Direction of Trade Statistics, World Bank WDI 
Graph 4.2: Real effective exchange rate, import basis

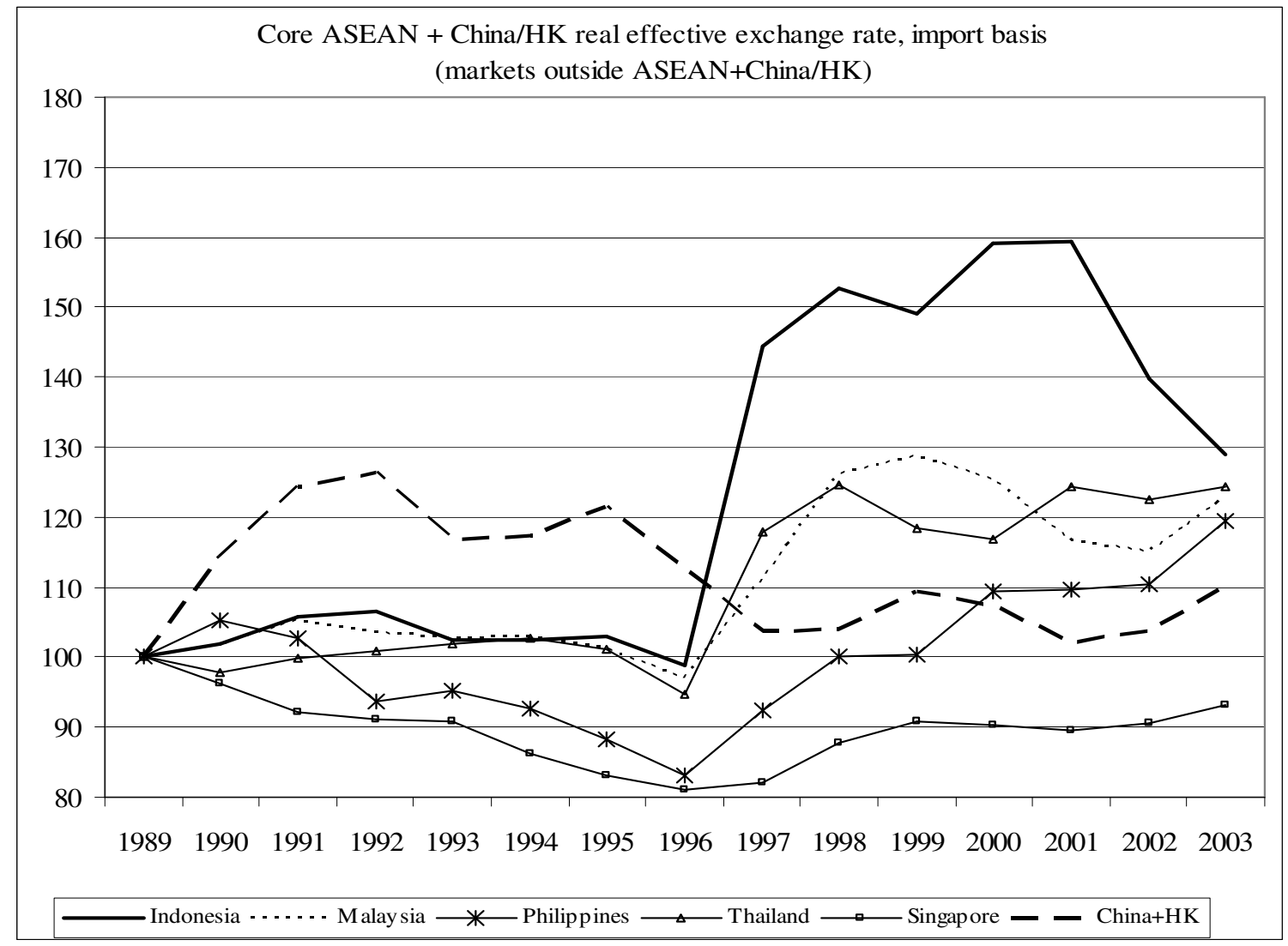

Source: Global Financial data, IMF Direction of Trade Statistics, World Bank WDI 
Graph 4.3: Real effective exchange rate, total trade basis

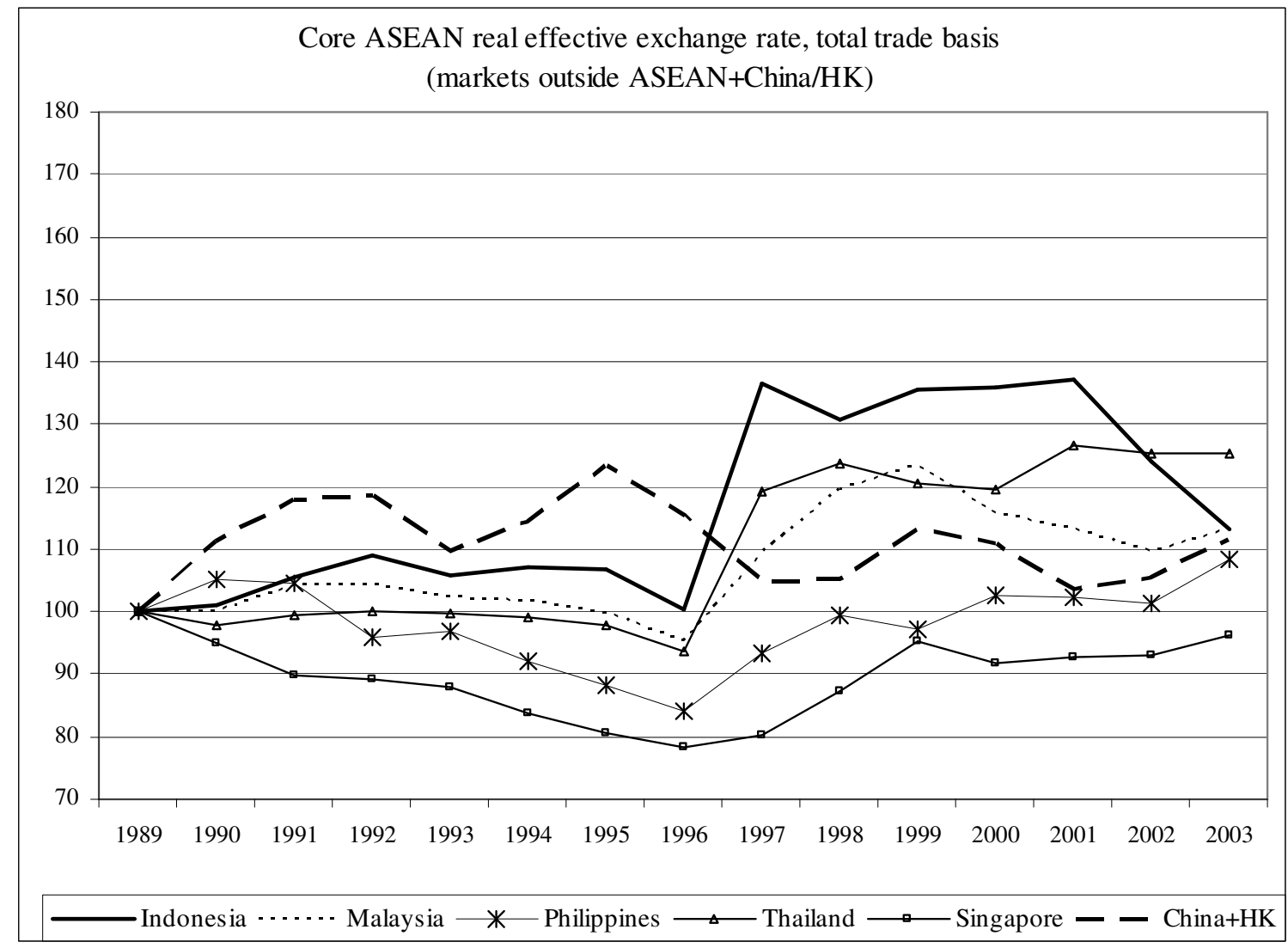


Graph 4.4: Weighted CPI indices for trading partners, core ASEAN and China+HK

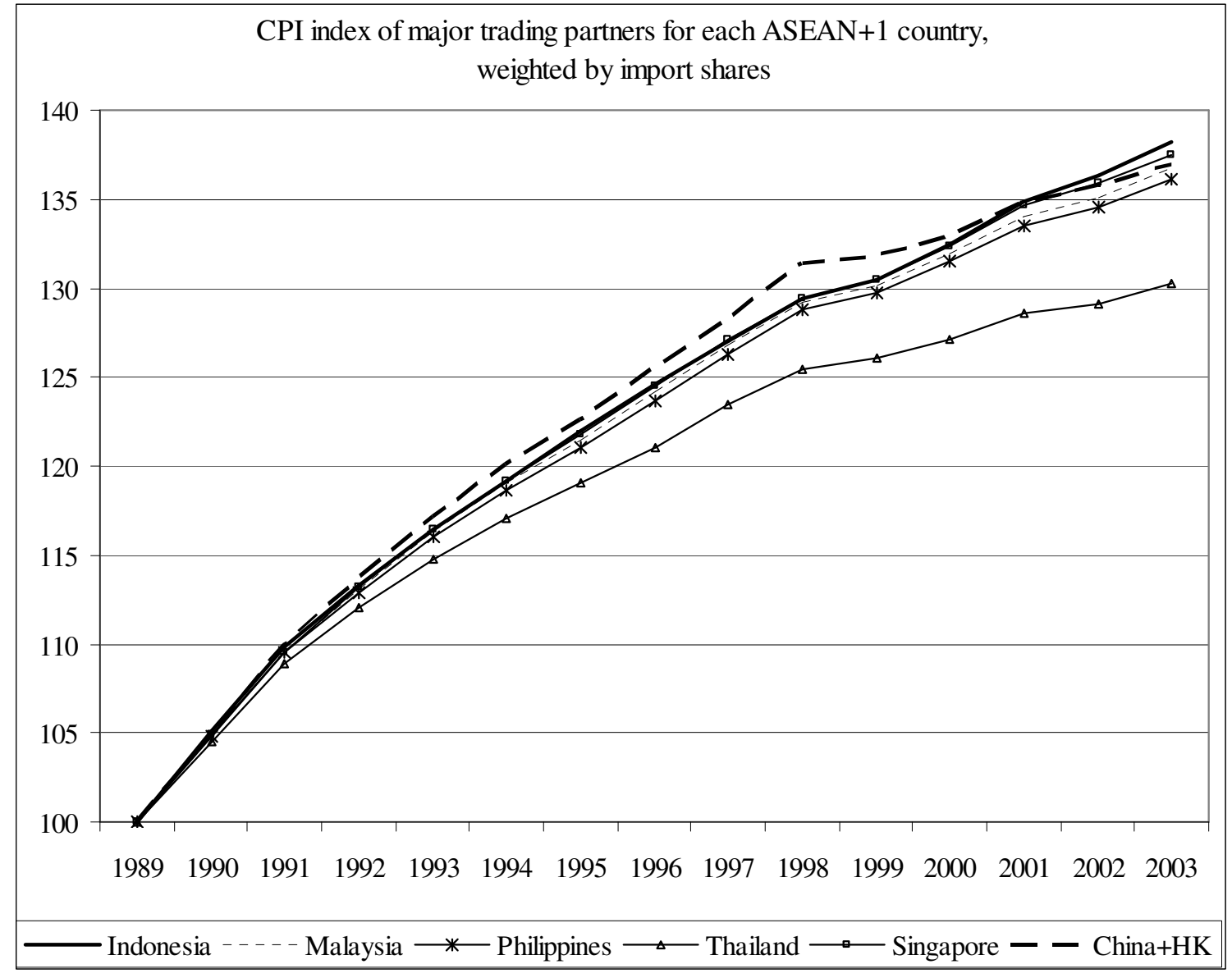

Source: Global Financial data, IMF Direction of Trade Statistics, World Bank WDI 
Graph 4.5: CPI indices for core ASEAN and China+HK

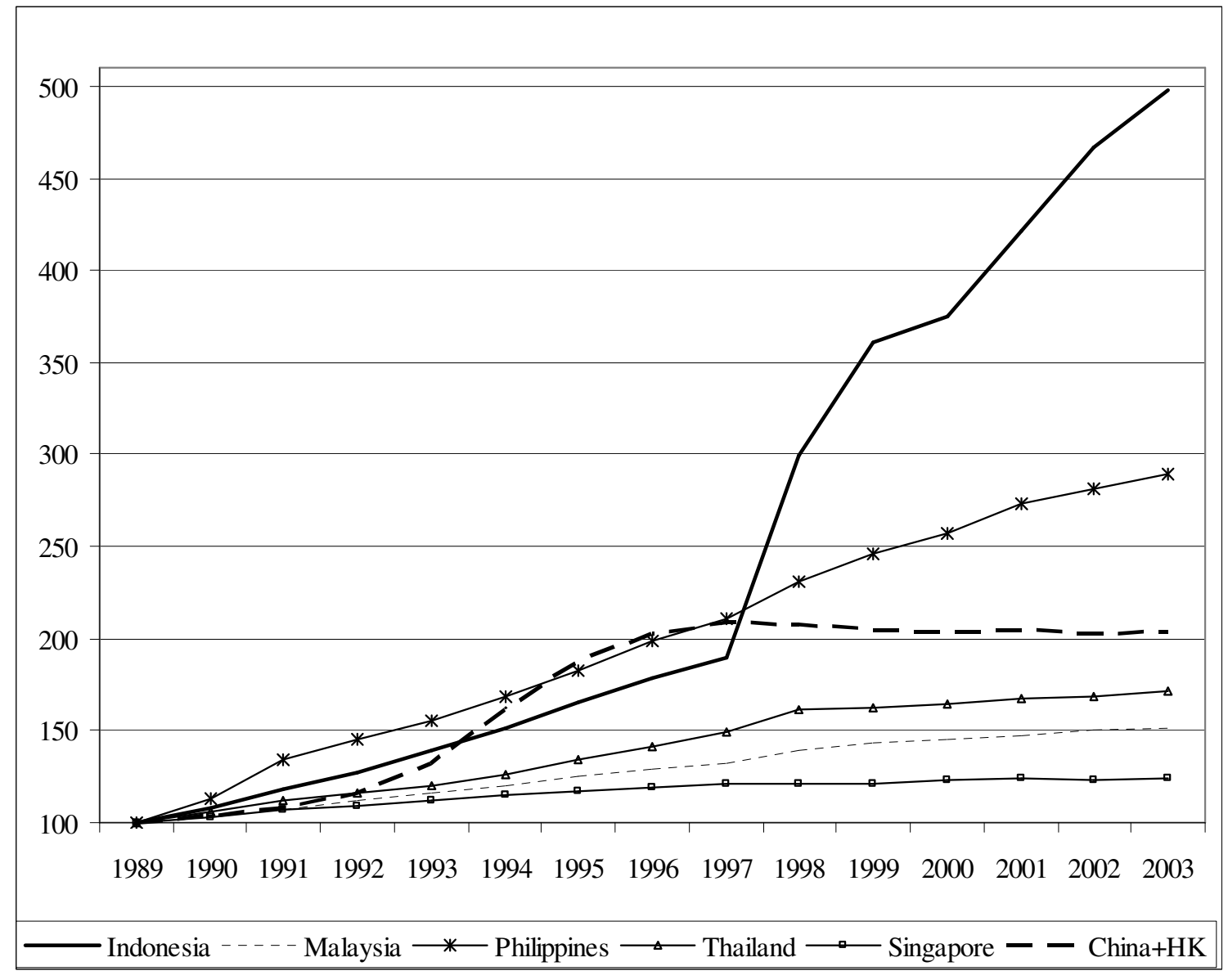

Source: Global Financial data, IMF Direction of Trade Statistics, World Bank WDI 
Graph 4.6: Nominal effective exchange rate, import basis

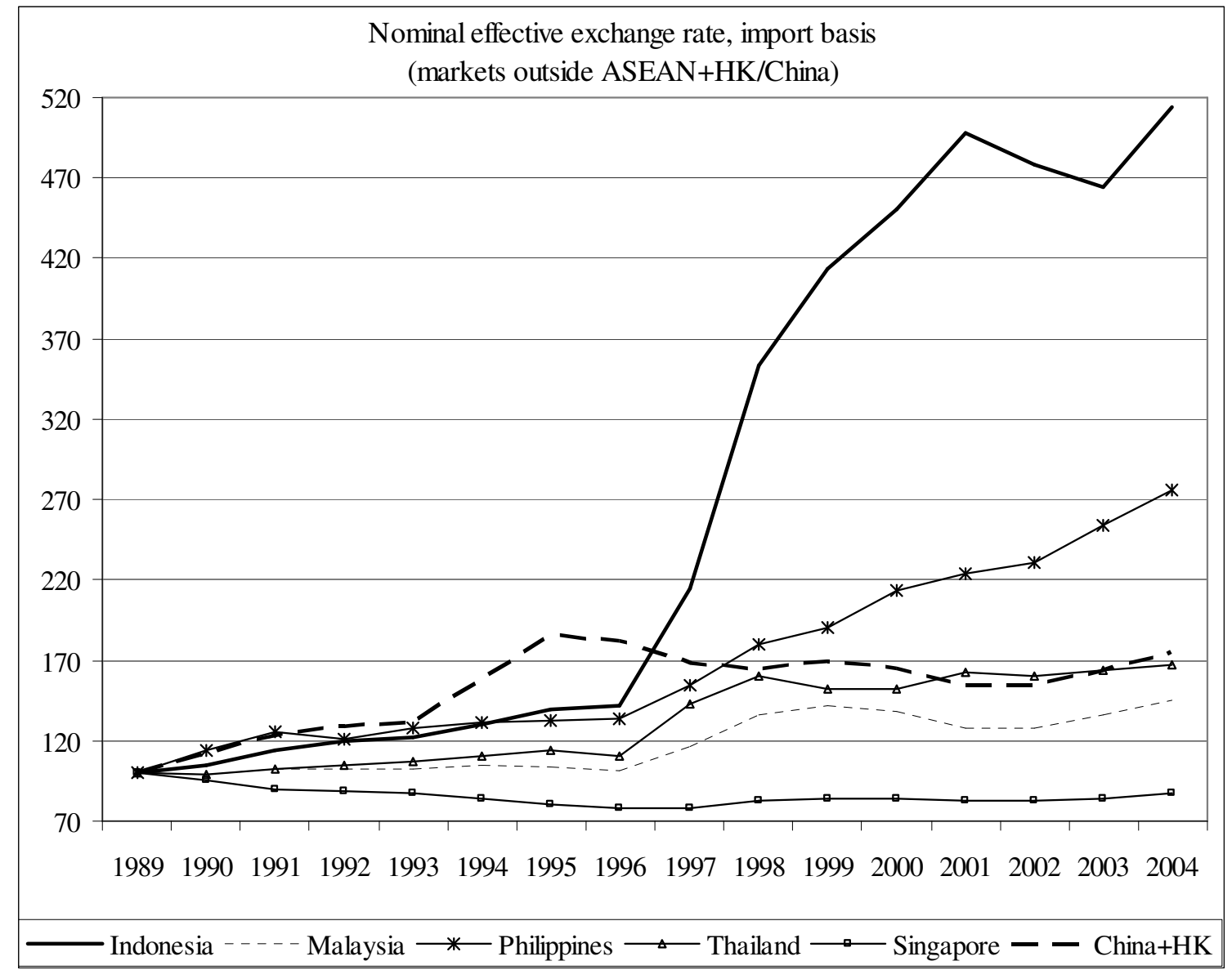

Source: Global Financial data, IMF Direction of Trade Statistics, World Bank WDI 
Table 5.1: Correlation matrix of monthly changes in dollar exchange rates, January 2000- June 2005

\begin{tabular}{|l|r|r|r|r|r|r|r|r|r|}
\hline & \multicolumn{1}{|c|}{ Indonesia } & \multicolumn{1}{l|}{ Malaysia } & Philippines & \multicolumn{1}{l|}{ Thailand } & Singapore & China & Japan & Taiwan & Korea \\
\hline Indonesia & 1 & & & & & & & & \\
\hline Malaysia & 0.15 & 1 & & & & & & & \\
\hline Philippines & 0.39 & 0.09 & 1 & & & & & & \\
\hline Thailand & 0.45 & 0.23 & 0.57 & 1 & & & & & \\
\hline Singapore & 0.54 & 0.32 & 0.33 & 0.65 & 1 & & & & \\
\hline Japan & 0.27 & 0.29 & 0.24 & 0.53 & 0.64 & -0.06 & 1 & & \\
\hline Taiwan & 0.11 & 0.07 & 0.36 & 0.62 & 0.33 & -0.11 & 0.36 & 1 & \\
\hline Korea & 0.25 & 0.20 & 0.19 & 0.47 & 0.47 & -0.01 & 0.57 & 0.60 & 1 \\
\hline
\end{tabular}

Table 5.2: Correlation matrix of monthly changes in dollar exchange rates. January 2000- June 2005

\begin{tabular}{|c|c|c|c|c|c|c|c|c|c|c|c|c|c|c|}
\hline & Indonesia & Malaysia & Philippines & Thailand & Singapore & Vietnam & Myanmar & Cambodia & Laos & Brunei & China & Japan & Taiwan & Korea \\
\hline Indonesia & 1 & & & & & & & & & & & & & \\
\hline Malaysia & 0.15 & 1 & & & & & & & & & & & & \\
\hline Philippines & 0.39 & 0.09 & 1 & & & & & & & & & & & \\
\hline Thailand & 0.45 & 0.23 & 0.57 & 1 & & & & & & & & & & \\
\hline Singapore & 0.54 & 0.32 & 0.33 & 0.65 & 1 & & & & & & & & & \\
\hline Vietnam & -0.07 & -0.15 & 0.31 & 0.05 & 0.03 & 1 & & & & & & & & \\
\hline Myanmar & 0.12 & 0.19 & 0.16 & 0.41 & 0.34 & 0.00 & 1 & & & & & & & \\
\hline Cambodia & 0.05 & 0.00 & -0.01 & 0.08 & -0.06 & -0.17 & 0.21 & 1 & & & & & & \\
\hline Laos & -0.10 & -0.02 & -0.15 & 0.00 & -0.22 & -0.05 & -0.03 & 0.65 & 1 & & & & & \\
\hline Brunei & 0.54 & 0.34 & 0.33 & 0.65 & 0.98 & 0.02 & 0.33 & -0.04 & -0.19 & 1 & & & & \\
\hline China & -0.18 & -0.11 & -0.27 & -0.07 & -0.15 & -0.17 & 0.07 & -0.03 & 0.08 & -0.15 & 1 & & & \\
\hline Japan & 0.27 & 0.29 & 0.24 & 0.53 & 0.64 & 0.06 & 0.35 & -0.06 & -0.19 & 0.58 & -0.06 & 1 & & \\
\hline Taiwan & 0.11 & 0.07 & 0.36 & 0.62 & 0.33 & 0.37 & 0.28 & -0.10 & 0.01 & 0.33 & -0.11 & 0.36 & 1 & \\
\hline Korea & 0.25 & 0.20 & 0.19 & 0.47 & 0.47 & 0.13 & 0.21 & -0.05 & -0.08 & 0.46 & -0.01 & 0.57 & 0.60 & 1 \\
\hline
\end{tabular}


Table 5.3: Correlation matrix of monthly changes in reserves, denominated in LCU (starting Jan 1999 $)$

\begin{tabular}{|l|c|c|c|c|c|c|c|c|c|}
\hline & Indonesia & Malaysia & Philippines & Thailand & Singapore & China & Japan & Taiwan & Korea \\
\hline Indonesia & 1 & & & & & & & & \\
\hline Malaysia & 0.07 & 1 & & & & & & & \\
\hline Philippines & 0.35 & 0.10 & 1 & & & & & & \\
\hline Thailand & 0.33 & 0.34 & 0.21 & 1 & & & & & \\
\hline Singapore & 0.37 & 0.73 & 0.29 & 0.51 & 1 & & & & \\
\hline Japan & 0.37 & 0.50 & 0.27 & 0.47 & 0.64 & 1 & & & \\
\hline Taiwan & 0.50 & 0.34 & 0.40 & 0.65 & 0.61 & 0.51 & 1 & \\
\hline Korea & -0.07 & 0.46 & 0.07 & 0.15 & 0.37 & 0.33 & 0.04 & 1 & \\
\hline
\end{tabular}

${ }^{1}$ China starting July 99

Source: IMF IFS; Taiwan CBC data

Table 5.4: Correlation matrix of monthly changes in reserves, denominated in LCU (starting Jan 1999²)

\begin{tabular}{|c|c|c|c|c|c|c|c|c|c|c|c|c|c|}
\hline & Indonesia & Malaysia & Philippines & Thailand & Singapore & Vietnam & Myanmar & Cambodia & Laos & China & Japan & Taiwan & Korea \\
\hline Indonesia & 1 & & & & & & & & & & & & \\
\hline Malaysia & 0.07 & 1 & & & & & & & & & & & \\
\hline Philippines & 0.35 & 0.10 & 1 & & & & & & & & & & \\
\hline Thailand & 0.33 & 0.34 & 0.21 & 1 & & & & & & & & & \\
\hline Singapore & 0.37 & 0.73 & 0.29 & 0.51 & 1 & & & & & & & & \\
\hline Vietnam & -0.22 & 0.55 & -0.15 & -0.07 & 0.45 & 1 & & & & & & & \\
\hline Myanmar & 0.00 & -0.15 & 0.06 & 0.10 & 0.02 & -0.13 & 1 & & & & & & \\
\hline Cambodia & -0.08 & -0.20 & -0.03 & -0.11 & -0.22 & 0.05 & 0.06 & 1 & & & & & \\
\hline Laos & 0.19 & -0.22 & 0.11 & -0.18 & -0.20 & -0.10 & -0.13 & 0.04 & 1 & & & & \\
\hline China & 0.37 & 0.50 & 0.27 & 0.47 & 0.64 & 0.45 & -0.14 & -0.13 & -0.03 & 1 & & & \\
\hline Japan & 0.50 & 0.34 & 0.40 & 0.65 & 0.61 & -0.26 & 0.27 & -0.13 & -0.11 & 0.51 & 1 & & \\
\hline Taiwan & -0.07 & 0.46 & 0.07 & 0.15 & 0.37 & 0.39 & -0.10 & -0.04 & -0.17 & 0.33 & 0.04 & 1 & \\
\hline Korea & 0.35 & 0.08 & 0.15 & 0.42 & 0.29 & -0.07 & -0.01 & -0.07 & -0.12 & 0.28 & 0.41 & 0.18 & 1 \\
\hline
\end{tabular}

